\title{
Between Political Myths, Dormant Resentments, and Redefinition of the Recent History: A Case Study of Serbian National Identity
}

\author{
Joanna Wygnańska \\ University of Lodz, Poland
}

DOI: http://dx.doi.org/10.18778/1733-8077.17.2.03

Keywords:

Discursive

Construction of

National Identity;

Serbian National

Identity; Case Study;

Research Findings;

Critical Discourse

Analysis; Public Art

Messages

\begin{abstract}
The subject of the article concerns the issue of constructing and reconstructing national identity. The object of interest here is a sociological case study of Serbian national identity. It includes reconstruction and interpretation of in-depth interviews conducted in Serbia with the representatives of Serbian symbolic elites. The concept of symbolic elites is approached in the discussed research from Teun van Dijk's perspective. Thus, they are individuals and groups directly involved in the production of public opinion, who have an impact on the content of publicly available knowledge, and the creation and legitimization of public discourse. The work is embedded in the methodological framework of Critical Discourse Analysis (CDA) and is based on the assumptions of the Discourse-Historical Approach (DHA). In this optics, the most important thing is the historical and social context of the studied process of the discursive construction of national identity. Therefore, the conclusions also touch upon the historical, political, and social perspective of the formation of Serbian national identity. The reflection also aims at presenting the analysis from the contemporary perspective (mainly in 2008-2020). Thus, paying attention to the political divisions in Serbia and the country's road to democratization and European integration, the discussed research study shows the comprehensive specifics of the studied national identity.
\end{abstract}

Joanna Wygnańska is an Assistant Professor in the Department of Sociology of Culture at the Faculty of Economics and Sociology, University of Lodz. She is a member of the research team in the Center of Biographical Research and Oral History, University of Lodz, and a research assistant and contractor in national and international research projects concerning biographical research. She is the author of the scientific monograph Oswajając bałkańskie demony. Rzecz o Serbii. Dyskursywne konstruowanie serbskiej tożsamości narodowej [Taming the Balkan Demons. The Thing about Serbia. Discursive Construction of Serbian National Identity]. Her research interests lie in issues of constructing national identities, transitions of Serbian national identity, discourse analysis, and biographical research. She is fascinated by the issues related to the impact of symbolic culture on social life, especially in the context of portraying social problems through the lens of contemporary cinema.

email address: joanna.wygnanska@uni.lodz.pl 


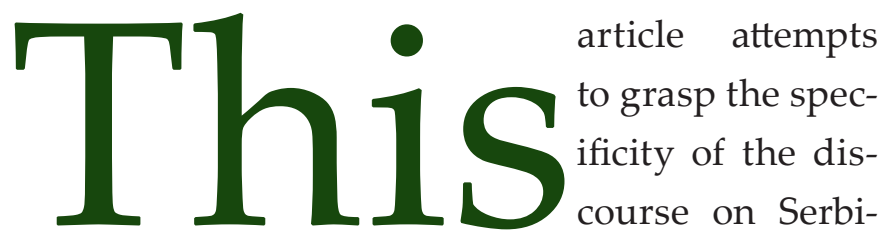

an national identity based on the conclusions from the analysis of the interviews with representatives of the Serbian symbolic elites ${ }^{1}$ and study of this identity changes in the last few decades. The aim of the text is thus, on the one hand, to present and reflect on the research study of Serbian national identity, which I conducted in Serbia a few years ago, and to focus on the contemporary perspective of this subject. ${ }^{2}$ On the other hand, in my reflections, I also try to show how the studied thread, which is inscribed in the analytical optics of concepts such as national identity, collective memory, national and political myths, or resentment, ${ }^{3}$ is also

\footnotetext{
${ }^{1}$ I conducted my research between 2012 and 2018. The interviews were gathered in Serbia in 2012-thanks to a special-purpose grant from the Polish Ministry of Science and Higher Education for activities related to scientific research or development work and related tasks for the development of young scientists. Still, the conclusions presented in the text also touch upon the perspectives of the present day. Between 2012 and 2018, I was in touch with some of the interlocutors and followed the political and social situation in Serbia, so the research study described in this text covers the perspective of the phenomenon under scrutiny over the past few years. In a much broader and much more in-depth study, the results of my research on this topic are presented in a scientific monograph (Wygnańska 2020), in which I juxtapose the statements of representatives of the Serbian symbolic elites with the selected statements of Serbian politicians from 1992-2018. In its socio-historical context and conclusions, the monograph also includes the perspective of years 2019-2020, important due to the recent parliamentary elections in Serbia (June 2020) and the social anti-government protests.

${ }^{2}$ Due to the COVID-19 pandemic, I was not able to complete the research revisit in Serbia in 2020 to conduct interviews with the representatives of Serbian symbolic elites, which could have brought a deeper perspective to this text, and, importantly, a comparative analytical thread. The revisit is being postponed for the second half of 2021.

${ }^{3}$ I understand the concept of resentment as approached by Ewa Thompson (2006:11 [trans. JW]): “to accept suffering, to feel humiliated by fate and people, to take chronic pity on oneself, to accept the attitude of a victim." I am aware that Thompson focuses on her reflections on the Polish context and reconstructs resentment by attributing it to the Polish
}

visible in the narrative of the urban space in Serbia and Kosovo. Thus, the research reflection presented here is complemented by a brief reference to the political and apolitical narrative on Serbian collective memory and Serbian national identity, which is told in Serbian public space-because some of the murals, graffiti, and inscriptions on the walls that have been created in Serbia and Kosovo refer to the analyzed issues. In the case of some of them, the space of remembrance is an inspiration, thanks to which the resulting visual constructs fit into the notions of Serbian national identity shaped by apolitical and anti-war rhetoric. In the case of others, the memory becomes a tool of political struggle. In this case, the topics raised in the form of visual representations in Serbian public space are, for example, the memory about the NATO conducting a bombing in 19994 and the opposition to the independence of Kosovo. In addition, the theme of NATO's bombing of Belgrade at the end of the 1990s is also present in Belgrade's public space in the form of buildings destroyed at the time, integrated into the developing urban fabric. ${ }^{5}$ In this way, they last gloomily, to remind of what happened in Serbia at the end of the last century. I would, therefore, like to show in this text a few examples of those images and threads related to the specificity of the discourse on Serbian national identity to briefly

nation features of postcolonial nations. However, taking into account this contrast between the analyses undertaken in my research and Ewa Thompson's conclusions, it can be assumed that resentment understood in this way is in line with the rhetoric of martyrdom present in the discourse on Serbian national identity.

${ }^{4}$ In the case of Serbia, the problem relates to the attacks by NATO forces, in which the US armed forces played a major role, and, in addition to the 1999 bombings in Serbia and Kosovo province, it also includes attacks on Serbs in Croatia and Bosnian Serbs in Bosnia and Herzegovina in the first half of the 1990s.

${ }^{5}$ I mean here the twin buildings of the Yugoslav Ministry of Defense and the General Staff and the Serbian Radio and TV building. 
outline in what form those meanings function in the urban space.

It should be stressed that, for me as a researcher, Serbia seemed interesting to explore the context of the construction of Serbian national identity for two reasons. Firstly, it is a country of opposites that are looking for common ground. It means that since the end of the 1980s, in Serbia, every idea taken in connection with the political or social vision of the country almost immediately gives rise to its denial. But, at the same time, despite this tendency to deconstruct and disintegrate, the Serbs desperately want to live together as a nation. And, in a sense, it is fascinating how they combine the separating visions of meanings about their national identity. Secondly, in the discourse about the disintegration and war conflicts in the former Yugoslavia, of all former Yugoslav republics, Serbia is the most blamed one for the collapse of the Federation. For a long time, Serbia was also burdened with the accusation of being the cause of the destabilization of the situation in the Balkan region and impeded the process of settlement of all former socialist Balkan countries with the wartime past. I was interested in such a distribution of guilt, especially when compared to Serbia's rhetoric based on the assumption of victimization of the nation and anti-Serbian plots. Furthermore, in Serbia, an interesting phenomenon is the relationship between the ruling and the intellectual elite. As it turned out (also partly in my study), the intellectual elite took much more sophisticated resources of symbolic power than the political one. This article, therefore, attempts to capture what lies on the borderline of the constructed social vision of Serbia and its everyday social reality. In this understanding, the text is partly a kind of report on the conducted case study of Serbian national identity, but also a reflection on its results, immersed in the historical perspective of the studied phenomenon and, at the same time, inscribed in the optics of the contemporary times.

\section{The Socio-Historical Context of Studied Phenomenon}

The discussed deliberations are based on the assumption of the discursive construction of Serbian national identity. In the case of such an expression, I mean both Serbian national identity in the sense of placing it within the socio-historical framework of the former Yugoslavia, as well as referring to the post-Yugoslavian Serbian national identity. Additionally, the discursive construction of national identity cannot be inferred without portraying the historical and social processes influencing the formation of the discourse on the particular identity. Therefore, when analyzing the case of Serbian national identity, it is extremely important to point out, among other things, the course of Serbia's path from the $19^{\text {th }}$-century idea of Yugoslavism and national visions referring to medieval tradition, through communist ideology acting in the spirit of unification of the six Yugoslav republics, to the times of radical, militant, and "resentment" nationalism $^{6}$ of Slobodan Milošević's regime, and the first years after its fall. Thus, it is important to analyze the $19^{\text {th }}$-century beginnings of Serbian nationalism and the description of the Serbian myths (such as

\footnotetext{
${ }^{6}$ The term "resentment nationalism" is used in the understanding of Nenad Dimitrijević (1999:112), who refers to this term when describing Serbian nationalism in the late 80 s and in the 90 s of the XX century. This nationalism was based largely on an extensive concept of Serbian martyrdom, a totalitarian policy, centered around the myth of national unity, aimed at constantly evoking the enemies of Serbian identity and culture with which the Serbs were to fight or against which they should unite. Dimitrijević, in writing about "resentment nationalism," refers to the text by Vesna Pešić (1995) devoted to the analysis of the break-up of Yugoslavia.
} 
"Kosovo Field's myth"7 and "Myth of the Serbian Nation" ${ }^{\prime}$ ) and visions of "Great Serbia" ${ }^{9}$ that are

\begin{abstract}
${ }^{7}$ The Kosovar myth, referring to the battle that took place in 1389 between Serbian troops, fed by allies from southeastern Europe, and the Turks, contributed to the sacralization of the Serbian nation. According to the Julian calendar, the battle took place on June 15, 1389, but due to the change to the Gregorian calendar, the date is June 28. Every year on this day the anniversary of the battle and St. Vitus' Day are held. In the Serbian tradition, the Battle of Kosovo Field symbolizes the Serbian sacrifice that this nation made on the altar of Christian Europe. In 1982, the Serbian Orthodox Church established the day of commemoration of the battle as a church holiday. The Kosovar myth returned with great force in the nationalist thought, awakened during the collapse of the Federal Socialist Republic of Yugoslavia. And in this "returning" the main idea of Serbian national identity was realized by popularizing the messianic idea of building Serbian historical consciousness based on the cult of "beloved" heroes and blurring the boundaries between religion and politics. As Zieliński (2001:33) emphasizes, this sacralization of Serbian history gives a mythical dimension to secular heroes and stories about their deeds.
\end{abstract}

${ }^{8}$ I refer to the "Myth of the Serbian Nation" presented by the Serbian essayist Ivan Colović (2001:18-19). According to this intellectual, when analyzing the discourse on politics and the nation of Serbia, it should be remembered that Serbia is one of the most involved in the national mythical narratives of states. The author reconstructed the "Myth of the Serbian Nation" by analyzing Serbian myths and Serbian populist tales, containing the most important motifs of the national legends and the components of the Serbian spiritual space.

9 The concept of "Great Serbia" was written in 1844 by Ilija Garašanin, holding the office of Minister of the Interior of the Serbian Principality, in his text Načertanije. Program spoljašne $i$ nacionalne politike Srbije na koncu 1844 godine [The Draft. The Program of Foreign and National Policy of Serbia at the End of 1844]. The idea of "Great Serbia" outlined, envisioned the creation of a Yugoslav state comprising Serbia, Kosovo, Northern Albania, Bosnia and Herzegovina, Montenegro, and part of Macedonia. The future map of a single state thus envisioned was a representation of the concept of Yugoslavism. A slightly different vision of the idea of "Great Serbia" was presented by the representatives of the Radical Party (Radikalna stranka, RS) formed in 1881 . The group's founders were inspired mainly by Russian nationalists. Their vision of "Great Serbia" was to unite all Orthodox believers in one state. In their idea of a common state, they, therefore, moved away from the "freedom of religion" proclaimed by Garašanin and from Vuk Karadžić's "linguistic" vision of a common nation. They advocated the unification of the Yugoslav state based on ethnicity. Another voice in the understanding of the idea of "Great Serbia" were the foundations of the Serbian underground organization "Unity or Death" (Ujedinjenje ili smrt), also known as the "Black Hand Organization" (from 1911). In its program, just as in the aforementioned ones, it referred to the idea of unifying all Serbian lands into one state, standing closer to radical solutions than the inclusive and tolerant form of nationalism represented by the Garašanin vision. In a slightly more contemporary portrayed in modern times in the discourse of politics in Serbia. The description of the so-called "third Yugoslavia" (1992-2003) existing within the framework of the mentioned "Great Serbia" recalled by Slobodan Milošević's regime is, therefore, crucial to understand the unique social creation combining communism with nationalism. Next, the perspective of Serbia since 2003, when the Federal Republic of Yugoslavia was dissolved in favor of the State Union of Serbia and Montenegro, should be taken into account. Finally, since 2006, after the breakup of the Union, it is important to recognize the issue of Serbia's contemporary situation both in the local and international context-and the understanding of the contemporary debates on the shape of the post-Yugoslavian Serbian national identity becomes significant. The case of Kosovo is also crucial here. I mean both the role that Kosovo plays in the Serbian national narrative and the consequences of Serbian-Albanian conflict and Kosovo independence ${ }^{10}$ as a source of the dispute in the process of building a dialogue between Serbian and Albanian politicians in Kosovo (and also the dialogue in the international sense). I am considering the matter of Koso-

perspective, the radical nationalism of Slobodan Milošević's regime used the vision of "Great Serbia" as a tool to unify the Serbian nation, excluding the assumption of ethnic and religious differentiation, and assuming the existence of an "ethnically pure" Serbian nation in the Yugoslav state.

${ }^{10}$ Kosovo's independence was declared on February 17, 2008. The process of establishing this state has led to increased tensions not only in the region but also in the wider international arena. As a result, Kosovo remains a state dependent on the European Union and NATO's support, unrecognized by many countries around the world (which, among other things, prevents its accession to the United Nations), and struggling with numerous internal problems, ranging from economic, ethnic, political, to those related to international organized crime in the area (including, among others, drug gangs and smugglers' actions). Thus, it seems legitimate to analyze the situation of Kosovo, the emergence and functioning of this state, which, due to the limitation of the volume of this article, I cannot fully make. For this reason, to explore the topic of Kosovo statehood in a very extensive and multithreaded study, see, for example, Pawłowski (2019). 
vo further in this article following the results of my study and the present perspective of this analytical thread. It should also be emphasized that, in the last few years, the dialogue on the political scene in Serbia is fading, including the voice of the opposition groups, towards the ruling power (SNS) ${ }^{11}$ accused of violating democratic principles, and is not a common voice. In such an atmosphere, part of Serbian society (between November 2018 and March 2020) took part in anti-government demonstrations under the name Jedan od pet milliona (opposing the system of the current power of Serbian President Aleksandar Vučić and proclaiming the need to normalize political life in the country). Thus, importantly, the conflict on the political scene also results in the polarization among the Serbian people themselves. ${ }^{12}$

Due to the limited size of this article, I will not discuss here in detail the above-mentioned intricacies of Serbian past and recent history, but I wish to point out that the characteristics of the historical, political, and social contexts of the formation of Serbian national identity are crucial to elaborate on the changes of this identity. Not only does it allow for an in-depth analysis of the relationship between past and present constructions of the Serbian national space, but it also allows us to see the

\footnotetext{
${ }^{11}$ Srpska napredna stranka (SNS)-Serbian Progressive Party. The Party won (again) in the last parliamentary elections on June 21, 2020. The holding of elections at a time of pandemic and the high prevalence of the winning party in the results led to protests of the political opposition and non-governmental organizations, as well as journalists not associated with the public media (presenting the voice of the main political option). Serbian President, Aleksandar Vučić, and his Party were accused of limiting the voice of the opposition in the election campaign, corruption, nepotism, and displaying authoritarian tendencies.

12 The year 2020 additionally brought the social protests provoked by the actions of the authorities towards the situation of the COVID-19 pandemic. The demonstrations lacked a clear political objective. They were primarily protests against the "Vučić regime" and constituted another stage of the protracted internal political crisis.
}

importance of the role of the political and intellectual elites in constructing the content of the two main discursive formations ${ }^{13}$ functioning in Serbia since the end of 1980s. I mean here the discourses of the "First Serbia" (Prva Srbija) and the "Other Serbia" (Druga Srbija). In the contemporary perspective, we can also talk about the phenomenon of the "Third Serbia" (Treća Srbija). ${ }^{14}$

At this point, it can be underlined that the discourse of the "First Serbia" is strongly saturated with nationalist ideology-it is conservative, Eurosceptic, and rooted in Serbian history and spiritual tradition (Russell-Omaljev 2016:20). On the other hand, the discourse of the "Other Serbia" was, in the beginning, formed around slogans opposing the militaristic, populist, and xenophobic nature of the political doctrine of Slobodan Milošević. Next, it was based on anti-nationalist and anti-war rhetoric, which brought to the forefront a fight for the rights of minorities (national, ethnic, sexual, and denominational) present in the contemporary political vision presented by the "Other Serbia." The phenomenon of the "Third Serbia" is visible in Serbian public discourse for a few years. The discourse of the "Third Serbia" is the most diverse and "seeking" of its identification. In a political sense, this discursive formation seeks to abolish the main division into the "First Serbia" and the "Other Serbia" and to introduce a kind of reconciliation that heals an allegedly unnatural split (Spasić and Pertrović 2012:221).

\footnotetext{
${ }^{13}$ I understand the concept of discursive formation as $\mathrm{Mi}$ chel Foucault, referring to the concept of discourse as a set of statements belonging to one formation system (Foucault 1977:150).

${ }^{14}$ Throughout the text, I leave the words "First," "Other," and "Third Serbia" in quotation marks. This decision results from the specificity of the discussed discursive phenomena. The statements produced within their framework are dependent on the historical, political, and social context.
} 


\section{About the Research-Methodological Assumptions and Ethnographic Considerations}

The study of the process of the discursive construction of Serbian national identity was based on the analysis of 31 in-depth interviews with representatives of the Serbian symbolic elites ${ }^{15}$ considered in recent socio-historical context and several statements by Serbian politicians from 1992-2018. In this text, however, I would like to focus mostly on the conclusions of the analysis of the interviews concerning the discourse of politics in Serbia. After gathering the interviews, I kept in touch with some of the interviewees, and while constructing my study, I asked them about the changes that I should take into account regarding the time that has passed since I visited Serbia in 2012.

The criterion for selecting the interviewees was my understanding of the symbolic elites as embraced by Teun van Dijk (1993:46) - individuals and groups directly involved in the production of public opinion that influence the content of publicly available knowledge and the creation and legitimization of public discourse. In such optics, symbolic elites do not fulfill the role of power over discourse in the traditional (political) sense and are assigned to symbolic power and some kind of control in the cultural and normative sense. Referring to the considerations of Marek Czyżewski, Sergiusz Kowalski, and Andrzej Piotrowski (1997:10-26), I also assume that the discourse of symbolic elites includes statements on political topics, which I call, after the authors, political discourse, and thus distinguish it

${ }_{15}$ The collection of 31 interviews contains recordings ranging from 1 to 3 hours, consisting of attempts by the interviewees to reconstruct the discourse at the level of collective and individual experience. from the political statements, which, after the authors, I recognize as the discourse of politics. Following van Dijk's approach, I assumed that I would interview Serbian journalists, the members of Serbian academia, people involved in social and political activities within non-governmental organizations (including pro-European organizations in the sense of their efforts to integrate Serbia into the EU), and people who belong to the intellectual elite and, at the same time, are active political activists. ${ }^{16}$ I started the interview process by contacting the academic community in Belgrade. The track was very good because the researchers were open to help me find the first interlocutors. I managed to reach the next interviewees by using the snowball sampling method. This method proved to be a good solution because reaching out to a few referrals at the beginning enabled me to conduct interviews and gain their trust. Furthermore, with their help and recommendations, I was able to reach out to more interviewees or places where I was looking for more people to interview. The saturation of the sample was determined, on the one hand, by the time limitations of my stay in Serbia under the research grant. On the other hand, after transcribing the collected interviews and then analyzing the collected research material for the first time, I had the feeling that I was dealing with a polyphonic and multithreaded collection of statements, concerning many issues, in which the process of the discursive construction of Serbian national identity is embedded.

The interviews were based on a list of information sought, thematic threads related to the historical and social contexts of the changes that have occurred in

\footnotetext{
${ }^{16}$ As a result of this approach, I gathered eight interviews with Serbian journalists, twelve interviews with Serbian Academia people, five interviews with Serbian NGOs' activists, three interviews with pro-European organizations activists, and three with political and social activists.
} 
Serbia since the fall of the Socialist Federal Republic of Yugoslavia. I was interested in questions of the dimensions of the phenomenon of Serbian nationalism, the rhetoric of the Serbian national narrative, including the narrative towards Kosovo, the perspective of stories about "Others" in the discourse on Serbian national identity, the transformation of Serbian collective memory, the role of the Serbian Orthodox Church and Serbian spiritual tradition in the construction of the discourse on Serbian national identity, and the relation between Serbian identity and Yugoslavian identity.

In analyzing Serbian national identity, I followed the assumptions of the (Viennese) Discourse-Historical Approach (DHA) of the Critical Discourse Analysis (CDA). I have been inspired by the network of notions proposed for the deliberations on discursive national identity by Ruth Wodak, Rudolf de Cillia, Martin Reisigl, and Karin Liebhart $(2009)^{17}$ with their extensive study of Austrian identity. DHA stresses that entering into a conclusion about a certain discursive fragment of social reality is a form of co-creating this discourse. This approach proposes that national identity is created through discourse and influences this discourse (Wodak et al. 2009:8).

Moreover, DHA assumes that national identity is subject to discursive macro-strategies (Wodak and Weiss 2004; Krzyżanowski 2008; Wodak et al. 2009). However, when analyzing the dimensions of these strategies of constructing and reconstructing national identity, it is necessary to pay attention both to the linguistic means of implementing the discourse strategy and to focus on the topos that accompany

${ }_{17}$ The first publication of the research conclusions was released in 1999. these strategies-the argumentation schemas/structures. In this perspective, the identification of thematic areas of content, as well as the recognition of their social and historical contexts by the researcher is complemented by the analysis of strategies and means and forms of their implementation. The whole analytical process makes it possible to derive a multi-faceted analysis of the discursively constructed national identity.

It is important to clarify that my research was based on the application of the concept grid proposed by the Viennese school. In this way, the research categories-the general framework of my conclusions-were embedded in an etic perspective. ${ }^{18}$ But, by reconstructing the discourse on Serbian national identity in relation to the content of the interviewees' statements, I delved into an emic way of interpreting the meanings (Pike 1967; Hymes 1978). The research study conducted in this way was an attempt to integrate the general analytical framework (the adopted conceptual grid and the ways of proceeding in the DHA framework) with the categories derived from the research material. In other words, in this research study, my aim was, on the one hand, to reflect the specificity of the discourse on Serbian national identity. On the other hand, I wanted to allow the voices of the interviewees to resonate in the research study I conducted.

Due to the direct participation of the representatives of the symbolic elites that I studied in the process of the discursive construction of Serbian national identity, the interviews with them should

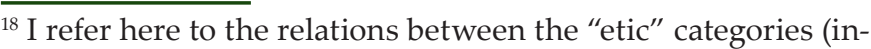
troduced from the outside by the researcher and used to build theoretical models) and the "emic" categories (referring to the description of the studied culture and social reality by showing the ways of its interpretation used by members of the studied communities).
} 
be also accompanied by a double commentary. First of all, the in-depth interviews (with a list of sought information) allowed the interlocutors to intertwine their expert narrative related to the discourse on Serbian national identity with their personal reflections. The question of this polyphony of the interviewees is an important research problem that I faced in my analysis of the material. The interviews I have conducted ${ }^{19}$ contain many narrative fragments rooted in the biographical experience of representatives of the Serbian symbolic elites. Thus, different levels of expression interweave in them, both those rooted in collective imagery and those rooted in individual experience, detached from objective meanings, which poses a difficult task for the researcher to ensure that the relation between the examined fragments of interviews and research conclusions does not create the impression of certain nonobviousness or even a detachment of conclusions from data.

In addition, it is important to stress that my empirical material consists of three types of statements of the representatives of the Serbian symbolic elites, and thus leads to three different approaches of how to infer them. First of all, the representatives of the symbolic elites performed in an interview as experts in the field of the discursive construction of the Serbian national identity. In such a situation, the interlocutors' statements remain here in a class/lecture tone. There is also no evidence of the inclusion of personal references in the described and evaluated contents. It must be emphasized that such cases among the interviews were the least present.

\footnotetext{
${ }^{19}$ I mean here both the interviews collected in Serbia and the statements of some of the interlocutors that I gathered during the analysis process.
}

Secondly, the representatives of Serbian symbolic elites constructed and reconstructed their views confronting them with other discourse / other discourses, and thus presented their thoughts (including personal ones) regarding the discourse on Serbian national identity and the discursive process of its construction. In such statements, the tone was more emotional, and the built-in patterns of argumentation were derived from personal experiences.

Thirdly, through their biographical experiences, the representatives of the Serbian symbolic elites were so much involved in the process of the discursive construction of Serbian national identity that they mainly focused in the interviews on their personal feelings. Such statements appeared in the gathered collection in many cases. These narrations were difficult to analyze in the methodological framework of the DHA, but they were also a very valuable image for the investigated phenomenon. These statements often balanced between entering a further biographical story and focusing on the subject of a single research question. In the analysis of these cases, we can see an aberration of the level of individual references to the discourse of Serbian national identity with attempts to reconstruct other discourses that have an impact on this discourse and their reconstruction in the personal reflection of the interlocutors.

\section{Research Outcomes}

\section{Part I. The Narrative of the Serbian Political Past}

In 2008, Dušan Kovačević ${ }^{20}$ published a book entitled Dvadeset srpskih podela (Srba na Srbe) [20 Serbian

\footnotetext{
${ }^{20}$ Dušan Kovačević (born 1948)-Serbian playwright, prose writer, screenwriter, theater, and film director.
} 
Divisions (Serbs to Serbs)]. It consists of stories that are a collection of voices, both individual and collective, that carry an almost age-old narrative about a nation that, in its desire for unity, persistently strives for the division. In Kovačević's text, the Serbs are the constructors of the mechanism of self-involvement in the search for what is Serbian, multiplying the repertoire of meanings of what is non-Serbian. The problem lies, according to the writer, in the fact that they were always like this-pro- and anti- something in the same time frame. And so the stories of Kovačević are amusing and disturbing at the same time. The quoted literary reflection is an important metaphor for the conclusions presented in this text. My deliberations are a kind of attempt to find out what is common-Serbian, national-in what is divided-anti-Serbian and above-national. Therefore, I intended to reconstruct this identity, capture threads and contents defining it, and search for ways to describe it.

I will present the results of the analysis concerning the narrative of the Serbian political past in relation to the fragments of two interviews with the representatives of Serbian symbolic elites. The themes explored in this section will focus mainly on the identity transition from Yugoslavian identity to Serbian identity (due to the collapse of the Socialist Federal Republic of Yugoslavia in 1992). The understanding of the dimensions of the relationship between these identity identifications is based on the voices of the interviewees. To begin with, I will refer to an excerpt from an interview with Ana, a journalist. Her involvement in public opinion in Serbia is not only about internal issues and problems. Ana is also professionally involved in writing about Serbia "outside," providing information about Serbian social and political reality to the Western media. When asked about her perception of what happened in
Serbia in the 1980s and 1990s, Ana's statement includes the following story:

When I worked in the 1990s in the newspaper [name of the local newspaper] of the opposition to the Milošević regime, we often had police checks and were suspected of acting against Serbia. Especially since we also dealt with international policy issues. And it was felt that, in those days, it was immediately perceived as anti-Serbian, and none of us had any intention of not being Serbs. We simply did not feel the little bit of extreme nationalism that Milošević used for his purposes. I remember I used to do a completely non-political article in primary school, and the headmaster refused to be interviewed by me because he decided that since I am a journalist from an opposition newspaper, I am working for the West and the Serbs should not collaborate with the West. And I did not understand it at the time. And I also have the impression that many such ordinary people did not know at that time what was happening next to them. They had their daily problems, and the official media did not give much important information, so many Serbs even then did not know that the crime in Srebrenica, for example, had happened. There were no statements of Serbian crimes at the time, mainly silence about Bosnia.

And that was the time when people tried to find this "new" [quotation marks added] Serbian identity. Until 1992 we were Yugoslavs, of course, you could also call yourself a Serb, but many, many Serbs called themselves Yugoslavs. Many people were looking for what it means that "now they can be Serbs" [quotation marks added].

My story here is perhaps worth mentioning because my father is a Serb from Montenegro and my mother is a Serb from Belgrade, and they always felt they were Serbs. They simply had Yugoslavian documents. So they didn't really understand what it meant either 
that "now they can be Serbs" [quotation marks added]. It was difficult for us to understand these sudden changes of identity, pointing out our enemies. So that's why before we started the interview, I asked why you are interested in the Serbs. And it's good that you don't write about us without talking to us, because it's a very difficult subject to understand what was and what is happening with Serbian identity. What was going on in Serbia. But, for me and my family, it was the identity we had like since forever and we didn't understand why it should suddenly be reborn in us after the collapse of Yugoslavia.

In her statement, Ana refers to many important issues for the analysis of the discourse on Serbian national identity. An excerpt from her experience of working in a newspaper in the 1990s revealed an interesting clue surfacing from the phrase said by the journalist: It is not right for Serbs to collaborate with the West. Following Zala Volčič, it can be explained here that, in Serbia, the construct of the imaginary West occupies one of the more important places in the national narrative about the enemies of Serbia and Serbianness. This perception is partly, as I have also been able to establish in my study, based on historical encounters of both perspectives, and is largely based on myths and stereotypes. In addition, it should be emphasized that the exploration of Serbia's multithreaded relationship with the West is necessary when studying the Serbian contemporary social reality. In this way, it is easier not to make the mistake of oversimplifying the explanations for Serbia's negative attitude towards the West in this regard (Volčič 2005:157).

It can be briefly mentioned here that the main reasons for the negative attitude expressed in Serbian public discourse about the West at the time mentioned by Ana in her interview were, on the one hand, resentments originating in Balkanism ${ }^{21}$ (Todorova 2008). On the other hand, it was a response to the discourse on the Balkans spread in the 1990s and created by the Western media reporting on the course of armed conflicts in the Balkans at that time. It is noteworthy that Western institutions and media stressed the fact that the former Yugoslav republics belong to the changing, in that time, Europe (I mean here 1990s), separating the Serbian nation from this "privilege." Mark Thompson's (1999) research report on the rhetoric of media coverage of events in Serbia, Croatia, and Bosnia shows that the media quite systematically emphasized Croatia's belonging to European culture and the world, and marked a deep regret for Bosnia and Herzegovina and the hostile, non-European, aggressive nature of Serbia. The anti-Western narrative of that time was most fully reflected in the discourse about Serbia and Serbian national identity represented by the Milošević regime, in which the politician very often stressed Serbia's regret for its "rejection" by Western countries.

Another noteworthy passage from Ana's statement is that she draws attention to the political and media "silence" in Serbia on the Bosnian war and the avoidance of a narrative on Serbian crimes committed in the 1990s. Tarik Jusić notes that Serbian media discourse in the early 1990s was both an indicator and a factor in the crisis of Serbian society, but also helped to promote and perpetuate the divisions inherent in the political narrative. Very often, the media either did not publicize inconve-

\footnotetext{
${ }^{21}$ Balkanism is a discourse related to the vision of the Balkan countries seen "outside of Europe" produced by the Western narrative. On the other hand, Balkanism also takes on a form of the phenomenon of Occidentalism, which in this case manifests itself in the narrative towards Europe produced by "non-Western" (in a sense of "not" European West) Balkan countries reaching also for the "hostile" rhetoric.
} 
nient issues or exaggerated the "wrongdoings" of other parties to the conflict (Jusić 2009:21). Jusić (2009:27) also refers to the conclusions of Dušan Reljić (1998:43), who calls the activities of the Serbian media in the 1990s the absolute domination of the reports written in the pro-regression and the production of a growing number of stories without sources. The information provided was, therefore, composed here in the name of eliminating alternative ways of interpreting it.

The issues outlined above show not the whole, but, to a large extent, the historical context in which Ana intertwines her statement and the social and political atmosphere of that time. Based on this and other collected statements of the representatives of the Serbian symbolic elites, I can point to two dimensions of the process of the discursive construction of Serbian national identity before ${ }^{22}$ and after 1992. ${ }^{23}$ The first one includes Yugoslavian identity, whose symbolic universe, ${ }^{24}$ in my opinion, could and still can continue after the fall of Yugoslavia. The second describes the Serbian identity "re-created" in the 1990s after the break-up of the Federation of six republics. In Ana's statement, we also come across expressions with negative connotations, "anti-Serbian" or "extreme nationalism," which also appeared in the statements of other interlocutors when they

\footnotetext{
${ }^{22}$ Since the establishment of firstly the Federal People's Republic of Yugoslavia (formed in 1946), later changed (in 1963) to the Socialist Federal Republic of Yugoslavia.

${ }^{23}$ Since the establishment of the Federal Republic of Yugoslavia (1992-2000).

${ }^{24}$ I understand this analytical resource according to Peter L. Berger and Thomas Luckmann (1966). I am also aware that, in this way, I introduce into the undertaken inference an element of symbolic interactionism, which thus belongs to a different theoretical order than the conducted discourse analysis. However, as a researcher, I concluded that the description of the phenomenon of Yugoslavian identity should be analyzed in relation to the phenomenon of intersubjectivity of meanings and everyday experience of a given social reality (Berger and Luckmann 1966; Schütz and Luckmann 1973; Schütz 2012).
}

reconstructed the discourse about Serbia's recent past.

Like Ana, in their statements on Serbian national identity, many of the other interviewees juxtaposed their personal identification with Serbian national identity with the discourse on the "new" Serbian national identity prevailing in the 1990s. In this way, by evoking the discourse about the "new" Serbian national identity, they tried to legitimize and justify the "reality" of the Serbian (ethnic) identity they had always experienced. Within the framework of a politically-created discourse on the "new" Serbian identity, they also sought a space for the functioning of the discourse on Serbian (ethnic) identity, which they represented and constructed in their statements. This situation also had the opposite effect, that is, by pointing to "their" discourse on Serbian identity, the interviewees tried to find in it an interpretation that would justify the "sensibility" or "necessity" of changing this discourse through the "new" discourse on this identity proposed in the 1990s.

In this perspective, it can be said that Ana's statement, and the statements of many other representatives of the Serbian symbolic elites that I have gathered, are particularly influenced by discursive preservative or justificatory strategies. They operate on the level of discourse about Serbian national identity inscribed in the perspective of the time before the fall of the Socialist Federal Republic of Yugoslavia. There can also be identified as the transformative discursive strategies visible at the level of the discourse on the "new" Serbian identity, related to the specificity of the discourse on politics during the Milošević era. The line of contention in the discourse on Serbian national identity visible in the statements of Ana (and other interviewees) is, therefore, 
a clash of beliefs about a certain essence of an identity related to the term origin (ethnic) and the level of political-citizen declarations giving this identity specific "national" connotations. Thus, at the level of discourse about the "new" Serbian national identity, the reconstructed transformative strategies aim at the autonomy of new meanings through the use of a rhetorical figure in the form of a metaphor and a reference to the pronoun "we" (we, Serbs). These strategies also serve a certain negation, one might say, of the appropriate shape of the previously existing Serbian national identity. Ana, in her statement, tries to separate the "we," with which she identifies herself (Serbian ethnic identity), from the "we" inscribed in the "new" Serbian identity created in the discourse of politics in Serbia in the 1990s. Ana sees the latter as a construct and, although she is unable to understand why it is only since the fall of socialist Yugoslavia that she can fully define herself as Serbian and what it means to be Serbian anew, she also reconstructs this aspect, which is important for the narrative on the past of Serbia.

As further deliberations on the narrative of the Serbian political past, I would like to recall a statement made by Jovana, a representative of the academic community. As a whole, her statement contains many narrative fragments in which the interviewee, answering general questions, recalls parts of her life story. In this way, the interview is also a record of certain key moments in the interviewee's identity development. Let us look at a fragment of the interview with Jovana:

In the 1980s, strong national feelings began to be awakened. And I lived in Belgrade at that time, and I was already politically aware enough to see how the dogma of "brotherhood and unity" was slowly being challenged by the elites against the ruling system.
And their ideology had a very strong nationalistic element. One could feel that it was very radical and I, for example, did not sympathize with it. I was a Yugoslavian patriot and I did not want the break-up of Yugoslavia. Of course, I was also critical of the communist regime and I wanted to change this ruling option. Many people wanted it.

But, like a large group of Serbs, I did not feel the need to separate Serbia or other republics from the country. I very much liked the idea of a community of several nations living together in Yugoslavia. This multiplicity made it possible for us to get to know what made us different, even though we seemed to have a lot in common as Balkan countries, the differences were important and often just interesting. I didn't feel that they increased people's sense of hostility.

I traveled a lot in Yugoslavia at the time, and neither I nor my parents ever thought that, for example, since we are in Croatia, this is a land hostile to our Serbianness. Although I was also aware that there is something in the air somewhere that is the result of some history, some myths, some kind of tension between ethnic identities. But, despite my critical view of the communist rule in Yugoslavia, I don't agree with the nationalist messages that declared that Serbs have to fight for their identity, that Yugoslavia threatens Serbianness. To this day, I don't buy this argument because I lived in Yugoslavia, I lived in Serbia at the time, and I didn't feel threatened.

Based on the analysis of this fragment of Jovana's statement and other similar statements of the representatives of Serbian symbolic elites, I reconstructed discursive preservative or justificatory strategies. In this case, they are related to maintaining the $\mathrm{Yu}$ goslavian identity and the narrative about it. These strategies are important in building a narrative that focuses on placing the discourse on a given national identity within a specific historical framework 
to justify its social status quo. In other words, to defend the existence of an identity with which an individual or group identifies and which has been somehow "contaminated" or the new order questions its legitimacy (Wodak et al. 2009:33). Thus, the topos of danger (in terms of losing the recognized world of meanings by the impact of the discourse about the fiction and creation of Yugoslavia) and the topos of belonging (in terms of recognizing the discourse about the Yugoslavian identity in telling about Serbian national identity) can be seen here.

When focusing on the events of the collapse of socialist Yugoslavia, Jovana also reconstructs the official discourse on abandoning Yugoslavian identification in favor of Serbian national identity. She also points to the collective nature of the problem she presented. Her personal references meet here a collective conviction that makes Jovana's voice socially empowered. Reconstructing the discourse on the political past, Jovana refers to historically established concepts such as Tito's "dogma of brotherhood and unity," "nationalistic element," "break-up of Yugoslavia," "communist regime." Additionally, those with which she does not identify are assigned negative connotations or personal and possessive pronouns, "it was very radical," "their ideology." At the same time, she also evokes the discourse about Serbian national identity in the 1990s to reconstruct the threat to the existing Yugoslavian and Serbian identity. Here, however, the Serbian national identity is still contained within the framework of the universe of Yugoslavia. She also raises a certain absurdity in the discourse on Serbian national identity in the 1990s.

In this short fragment, we can see, therefore, many discursive tracks. Firstly, a reconstruction of the discourse on Serbian national identity in the narra- tive of the political past. Here the context emergesthe nationalist messages that produced the idea of a struggle for a "new" Serbian identity. On the other hand, a reconstruction of the argumentation prevailing at the time that, "Yugoslavia threatens Serbianness." Furthermore, there is a lead that identifies the polarization of the discourse on Serbian identity (from the 1990s)-Serbianness is no longer part of the Yugoslavian narrative as it was in Yugoslavian discourse. In the "new" optics, Yugoslavian narrative and Serbianness are separate concepts and are assigned to two different orders of meanings.

In addition, Jovana's statement and several other similar statements I have collected are difficult to explain only by the phenomenon of nostalgia. Stuart Tannock (1995:454), referring to Raymond Willams (1973), comments that nostalgia as a structure of individual feelings evokes a positive assessment of the past and the related everyday world of life in response to the shortcomings and imperfections of the present reality. Nostalgia causes the individual to seek in the past the sources and the foundations of one's identity. In the present, one feels emptiness, danger, and a lack of important sets of recognized meanings. In the context of the former Yugoslavia, therefore, one can speak of yugonostalgia, which should be understood in three ways. First of all, it touches upon the evocation of memories and identification with (socialist) Yugoslavia in the form of opposition to nationalism that was gaining in importance in the 1990s. Secondly, it functions as a concept assigned to cultural, historical, and political space. Thirdly, it takes root in pop culture, for example, it is nostalgia for Yugoslavian music, Yugoslavian cinema, but also, as in the case of titonostalgia, it can be associated with selling the image of former "heroes" in pop culture (Jagiełło-Szostak 2012:241). Jovana, on the other hand, expresses her 
opposition to the break-up of Yugoslavia and the "radical nationalism" that was awakened at the time, but also defines herself as a Yugoslavian within the framework of contemporary times. It seems too simplistic to attribute to such statements, gathered in my study, only traces of yugonostalgia. The fragment of the interview with Jovana presented as an example of the discussed phenomenon of the duration of Yugoslavian identity can be recognized rather as a discursive formation showing the clash of two discourses within the reconstructed process of the discursive construction of Serbian national identity. The first concerns Yugoslavian identity and does not exclude the existence of Serbian identity. Jovana makes it clear that (in the late 1980s and early 1990s) she lived in Yugoslavia and lived in Serbia, she does not overlook the Serbian context. The second discourse on Serbian identity, functioning in the 1990s, sought, as can be seen in the interviewee's statement, to differentiate between Serbian and Yugoslavian meanings. Importantly, the "permanence" of this identity is maintained only by means of references to the narrative of the past, with a simultaneous indication of the present. For there is no longer a Yugoslav state and nation, there is no and never has been a Yugoslavian language. And yet, returning to the already mentioned concept of the symbolic universe, this identity is maintained in an individual biographical experience. That is why it is so important to go beyond the discursive analysis to describe the phenomenon of this identity's permanence in a contemporary perspective and to undertake a study of Yugoslavian identity at the level of the biographical experience of individuals, which because of the character of my interviews I could not fully do.

To make the historical and social context in which Ana, Jovana, and other unquoted representatives of the Serbian symbolic elites functioned more transparent, a few more points should be stressed. In an attempt to explain the phenomenon and the paradox of Milošević's rule, one can say, after Eric D. Gordy (1999:3), that there are two spheres here. The first one concerns inciting ethnic hatred among the Serbs, which in some circles has been perceived rather as a fight for a "threatened" nation. The second is to ensure that the leader has no alternative political options to him. This is also what the interlocutors said-that Milošević "effectively eliminated or silenced" the opposition's opinions against his rule. Gordy (2005:184) also believes that for any integration of nations divided in the early 1990s, the accumulated legacy of the conflict and the memory of war is a serious obstacle.

One can also say that in the discourse on Serbian national identity, Orthodox traditionalism meets ethnonationalist ideology. In this optics, the mythical and messianic concept of the Serbian past, extended in time to the present and even the future, seeks its anchorage in the universalist values of equality and solidarity, combining a real discussion of the rights of the Serbian people (especially in the sense of the Serbian population living in Bosnia and Kosovo) with the "eternal" characteristics of Serbian national identity (Malešević 2002:154).

In the discussed perspective of producing a discourse on Serbian national identity after the collapse of Yugoslavia in the early 1990s, it is, therefore, noteworthy that Slobodan Milošević is also one of the creators and destroyers of the "new" Serbian national identity (discursively produced in the 1990s). Considering rhetorical styles, Thomas Lessl mentions the "bard's voice" or "bardic discourse." In such statements, the "bard" is an integral part of the group with which they communicate by adapting 
their rhetoric to the "voice" of the audience. Lessl (1989:184) notes that when the bards speak, their voice is like our voice that we hear, the one we associate with the collective consciousness that lives in folk poetry, legends, and myths. Lessl (1989:188) adds that bards remind people who they are, while priestly rhetoric reminds them whom they can become. On the other hand, analyzing the history of Yugoslavia, Serbia, and Croatia, Siniša Malešević (2002:303) sees that all three cases are characterized by the legitimacy of the regime through the figure of a charismatic and "folk" leader. Communism in Yugoslavia during Tito's reign sought the unity of many nations in one country. The Milošević regime manifested itself in the idea of uniting all Serbs. The leader became a symbol of Serbian nationalism, or more precisely-of ethnonationalism, taking unification measures only towards the Serbs. The Croatian President, Franjo Tuđman, who in the 1990s was writing the "new" visions of the recent and "old" history of Croatia, also influenced the crowds. In the case of Milošević, it can also be stated that he not only used bardic discourse but also combined it with priestly rhetoric. He reminded the Serbs of who they are and, at the same time, offered them a vision of who they can be. That is why the representatives of the Serbian symbolic elites whom I interviewed devoted so much space to him in their interviews.

In addition, this part of the discussion should point out the current phenomenon of relations between national myths and Serbian history and politics. In this perspective, "myth transforms the relations established historically into ahistorical and a priori relations. Myth neutralizes history in such a way that the consumer of myth treats signifying as a system of facts" (Wasilewski 2006:478 [trans. JW]). In the myth as a form of social communication, there are two main spheres. The first one is gnosis, "pro- viding stability and seeming rationalization. It manifests itself in the form of a description, a narrative referring entirely to past facts, and thus directly related to collective memory" (Lewandowski 2015:73 [trans. JW]). The second is "faith in the form of a priori assumptions," which serves to maintain the "truthfulness" of the gnosis and allows us to combine "incoherent, doubtful, and even antagonistic elements of myth" into a whole story, which its "preachers" reach for in a specific socio-cultural context (Lewandowski 2015:73 [trans. JW]). In this way, the Serbian national myths used in the discourse of politics can be considered within the framework of cultural axiology and social doctrine, and thus as an element mediating the construction of the Serbian collective memory. Examples of references to the fatalistic atmosphere of the Serbian national myths can, therefore, be found not only in the $19^{\text {th }}$-century "Great Serbian" narratives, but also in the actual contemporary attempts at new readings of history. Although in Serbia, there is a discourse of the symbolic and political elites visible that tries to redefine Serbian collective memory, which is in the chaos of meanings, by seeking liberation from the messianic narrative, the myth still plays a significant role in the process of shaping Serbian national identity.

The narrative on the Serbian recent past thus contains historical references, manifested in the memory of former Yugoslavia, the rule of Milošević, the awakening of Serbian nationalism, but also those evocating the times of the captivity of Serbia under the Ottoman Empire, as well as mythical and symbolic references to the memory of the Battle of Kosovo Field and Serbian messianism.

Referring to the presence of the threads I have investigated in the narrative of Serbian urban space, out- 
lined in the introduction to the article, I would like to draw attention to a mural in Belgrade, which is not titled, but can be recognized as "People without faces." It depicts the phenomenon of the collapse of structures and, therefore, can be interpreted as the picture of Serbs after the fall of the Socialist Federal Republic of Yugoslavia-as seekers of their identity. It was created in 2014. The author MISHA MOST enters this work into the series "Situation." The artist's website states that the series consists of "situations filled with humans from today's world." 25 The artist has entangled in "Situations" both those whose biography is marked by the traits of symbolic bullets and those who "kill each other with the idea of mythical 'freedom' in their head." The author mentions those who are often hostage to certain systems and become liberated from them in time. The artist also touches on the changes that people face and the emotions that accompany them.

I spoke with the interlocutors about this project of MISHA MOST and some of them captured it as a moment of the collapse of Yugoslavia, and thus the transformation of the national identity in Serbia. In this interpretation, Yugoslavia and the "new" Serbianness are illustrated here by the blue belt of the (Serbian) flag inscribed in the mural. It is filled with a multitude of documents, once Yugoslavian, now Serbian, identity cards. In those documents persist the faces of the Serbian inhabitants, who, like in the stories of the interlocutors, have been kind of suspended between two narratives about their national identity, and which are blurred on the mural. In this interpretation, this mural can exist as a story about a state of transition from one identity to another or an attempt to find a common space for once shared and

\footnotetext{
${ }^{25}$ See: http://www.mishamost.com/situation. Retrieved May 16, 2020.
}

now often treated as separate meanings. Two photos of the mural are shown below.

\section{Photo I}

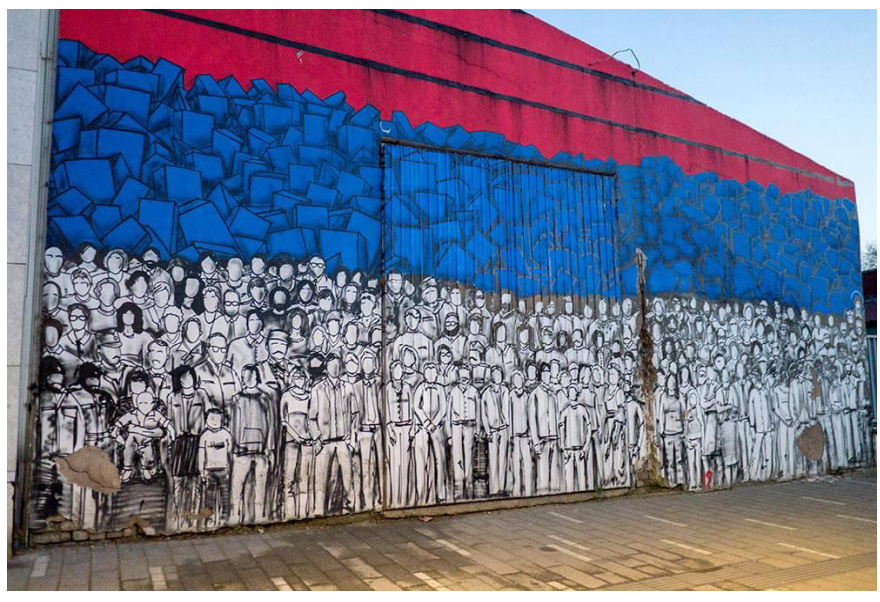

Source: https://peekingduck.cola-street-art-guide-to-belgradel. Retrieved May 12, 2020.

\section{Photo II}

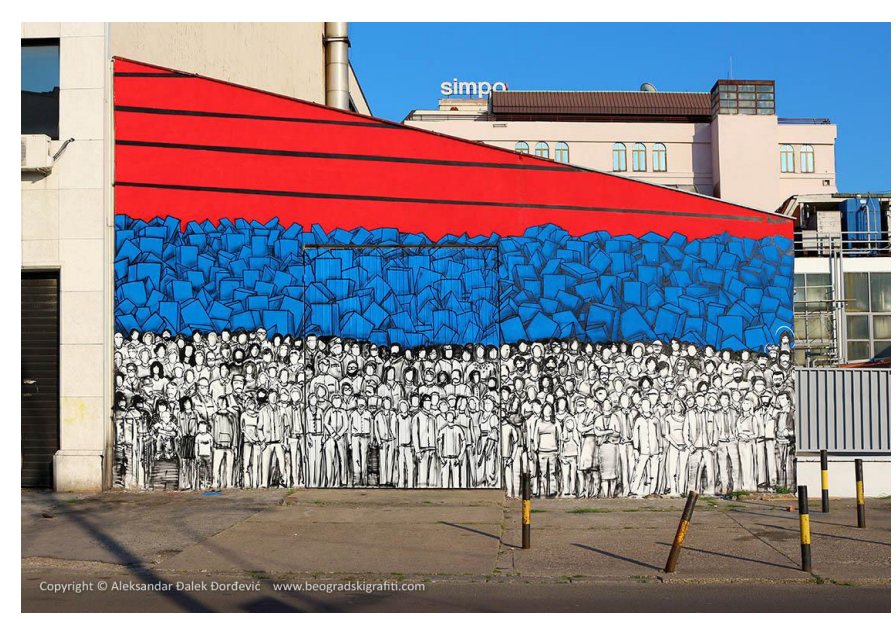

Source: https://streetartbelgrade.com/galerija/misha-most-narod-savamalal. Photo: Aleksandar Đalek Đorđević. Retrieved May 12, 2020.

\section{Part II. Serbian Narrative about the Present and the Future}

In terms of the narrative on the present and the future of Serbia, my study reconstructed three 
discursive leads. First of all, the discourse about Serbia's membership in the structures of the European Union (EU): anti-European and pro-European. Secondly, the discourse about the Serbian tradition, which in many of the gathered statements of Serbian symbolic elites was reconstructed through linking the Orthodox tradition of Serbia and Russia. Thirdly, the discourse about the still divided, due to the clashing discourses of the "First Serbia" and the “Other Serbia," vision of Serbian national identity.

Referring to the first issue, it can be emphasized that the political voices prevailing in Serbia after the departure of Milošević deemed the military solutions taken by the regime in the 1990s as bad and working against the unity of the Serbian people (Judah 2002:160). The Great Serbian aspirations of the former leader also harmed the Serbian population outside the country (in Croatia, Bosnia and Herzegovina, and Kosovo). And the permanent refusal of the then authorities to admit having committed war crimes by Serbia also contributed to the falsification and gaps in the collective memory. Jelena Subotić (2011:319) comments that the case of Serbia's accession to the EU was then regarded as an official preference at the national level and was within the scope of civil society aspirations. However, at that time, the European ideal itself did not find a chance to develop within Serbia into a coherent narrative. The anti-Western, anti-European policy of the time of Slobodan Milošević, which certainly contributed in some way to the demarcation line between Serbia and Europe at that time, can be viewed as having contributed to this. Since 2014, Serbia has been an official candidate for the EU. When considering Serbia's chances of joining the EU, Marko Babić (2012:116) points out the need to carry out a critical reflection on nationalism and the war, and to control the dichotomy of Serbian identity torn between the national self and a pro-European attitude. He also refers to the reflections of former Serbian Prime Minister, Zoran Đinđić, who in the 1990s called Serbia "an unfinished state with a belated nation" (Babić 2012:115 as cited in Đinđić 1996 [trans. JW]).

It is also important to recall the issue of Kosovo's independence, which, in 2008 when Serbia was approaching Europe, aroused dormant resentment. Thus, the country once again needed time to return to the path of integration with Europe. It is worth referring here, after Yelena Subotić (2011:325), to the words of Serbian President, Boris Tadić, who, in 2007 said: "Kosovo is where my nation's identity lies, where the roots of our culture are. Kosovo is the foundation of Serbia's history and this is why we cannot give it up."26

Another thread mentioned above touches on the symbolic and, to some extent, the political bond between Serbia and Russia. These relations are marked in Serbian public discourse by a community of faith (Orthodoxy), language (Cyrillic), and, as the interlocutors have mentioned, support for the Serbian protest against the independence of Kosovo is also at stake here. Russia was one of the countries that criticized the West for its "unilateral" decision to establish the Kosovo state. ${ }^{27}$

In this part of the text, however, I would like to focus on the Kosovo theme ${ }^{28}$ and quote an excerpt

\footnotetext{
${ }^{26}$ Extract from an interview with Tadić on a Serbian radio station B92 on May 25, 2007.

${ }^{27}$ To read more on Serbian-Russian relations, see, for example, Patalakh (2018).

${ }^{28}$ To understand more the causes of the Serbian-Albanian conflict it should be noted that Albanians are pointing to the hostile actions of the Serbs since the 1960s and "ethnic cleansing," which they consider to be the main means of radical actions by the Serbs in the course of the dispute. Nor do they accept Serbian claims against Kosovo, believing that Kosovo
} 
from the statement by Ivo, an academic professor who is also involved in social activities in democratic associations and in commenting on religious and ethnic disputes in the Serbia and Balkan region for the Serbian and Western media. When talking on the issues that affect the discourse on Serbian national identity, he comments:

The divisions in talking about the Kosovo problem are probably the best illustration of what has been happening in Serbia since, say, 2006 and certainly since 2008. As you know, Kosovo hasn't been within Serbia for a long time, and there is no chance of its inclusion within Serbia without another war. It exists as a separate state and we have no influence on the withdrawal of its independence. But, our political discourse is still rooted in talking about regaining Kosovo.

There are, of course, more rational politicians who understand the situation, but, in public discourse, such voices are still lost in the face of speeches about the symbolism of Kosovo and about the threats towards Kosovo Serbs of the Albanian government in Kosovo...In addition, between 2000 and 2003, after Milošević's departure from power, Kosovo was not a particularly frequent political subject. It was not until 2004 that this issue came up again. And, in Serbia,

has always been only a "colony" or a small province of Serbia-in terms of the size of the land inhabited by the Kosovo Serbs. The opposing side of the dispute, the Serbs, are pointing out the hostile actions of the Albanians, referring to the issue of forced migration of Serbs from Kosovo in the 1960s and 1980s. As an argument to justify the armed struggle, they stress the need to protect the Kosovo Serbs and the heritage of Serbian spiritual culture in the region. The intensification of the conflict in the 1990s was also supported by the Western media, which, as in the case of the war in Bosnia, made the Kosovo dispute a space for the process of exposing victims and criminals, which was not always consistent with the historical relation. In the more contemporary perspective, the Serbian-Albanian relations are still in some way turbulent since the proclamation of the independence of Kosovo in 2008. To read more, see, for example, Živković (2011), Zdravković (2006), Nikolić (2003), Judah (2000), Blagojević (2003), Bieber (2002), Pawłowski (2016; 2019). we are dealing with a completely abnormal situation that has two faces.

The first one normalizes this abnormality and, as the voice of a certain part of society says loudly, Kosovo has been lost, Serbia should let go and deal with domestic and international politics in the country. And this is a private level of discourse about Kosovo. There is no end in the public message, mainly political, of the narratives about Kosovo's belonging to Serbia and the need to fight for this sacred land. And this is the creation of Serbian political elites, but also symbolic, because some intellectuals, writers, Orthodox bishops, and scientists represent such a position based on myths immersed in medieval history that Kosovo and Serbia are one.

Unfortunately, there is still no willingness and consent in Serbia to promote the content of the loss of Kosovo and leave this matter behind. So we have a difficult situation in Serbia because you cannot expect the whole nation to base its faith on the possibility of regaining Kosovo on a medieval myth. But, unfortunately, some people also strongly believe in this story of power and build their sense of belonging to Kosovo on it, and this drives politicians.

In Ivo's statement, the topos of losing Kosovo and the topos of belonging to Kosovo are recalled. The first one is an argumentation scheme specific to the discursive transformative strategies reconstructed in many gathered statements of the representatives of the Serbian symbolic elites. When talking about the Kosovo issue, the majority of the interlocutors pointed out the need to transform the discourse on Serbian national identity concerning the rhetoric about this matter. They also stressed the need to weaken in this discourse the power of identification with Kosovo in the sense of the Serbian territory (Serbian land), and to leave it only in the dimension of symbolic identification. This new identification on a symbolic level 
should also locate Kosovo's experience in the sphere of its historical past, without relying on the faith in Kosovo's return to Serbian borders. The second strategy belongs to the discourse of politics and, in his statement, Ivo reconstructs it on the level of experience of Serbian society. The discursive constructive strategies can be recognized here in the area of the discourse of the politics in Serbia, in which the topos of belonging to Kosovo leads to the construction of the unity of Serbian thought on the independence of Kosovo. Serbian politicians, not all but a large part of them, when speaking on the issue of Kosovo, identify their voice with those of Serbian people, establishing a vision of one common Serbian thought on the independence of Kosovo. "Failure to work" on the issue of Kosovo's independence at the level of discourse of the politics in Serbia may still influence the discourse on Serbian national identity for a long time. In Kosovo, one could say, the whole paradox of Serbian history is beginning and ending at the same time because to dissociate themselves from the political past associated with the Milošević regime, more contemporary political leaders and national speakers are using the symbolism of Kosovo in the same exaggerated way as Milošević did. Moreover, the rhetoric of the discourse of politics in Serbia towards the issue of Kosovo has been and continues to take the form of conspiracies to find traitors or opponents to the Serbian nation. In other words, the accentuation of various forms of "they" who conspire against "us" is visible here, and so these discursive incidents are part of the populist rhetoric. It sees "those" unfavorable as a threat to "our" national cause. And when the morality of such rhetoric is woven into this statement, such rhetoric very quickly takes up the form of "good" and "bad," outlining a dichotomous vision of the world supported by the topos of history and the topos of the savior of nations (Wodak 2015:67-68). These kinds of statements are, therefore, present mostly in the discourse of the "First Serbia," emphasizing the importance of Kosovo in the spirituality of every Serb.

In addition, the issue of Kosovo's independence is also present in the urban space narrative in Serbia and Kosovo. Thus, it is worth pointing out two of the many murals present in this context, which are part of the local and international discussion on the independence of Kosovo. The first one is located in Belgrade (New Belgrade, to be precise) and is seen as a message for Russian President Vladimir Putin and (former) US President Donald Trump. This message, however, has a double dimension-on the one hand, reminding Russia of the need to continue its support for Kosovo's non-independence. On the other hand, it is directed at the (former) President of the US, with a reminder of Serbia's position towards losing Kosovo, due to the US purpose of controlling the conflict between the Serbian and Albanian governments over Kosovo and the insistence on concluding an agreement between Belgrade and Pristina. Thus, the mural, presented below includes an outline of the Kosovo state and the notation written in three languages: Serbian, Russian, and English, which says: "Kosovo is Serbia."

\section{Photo III}

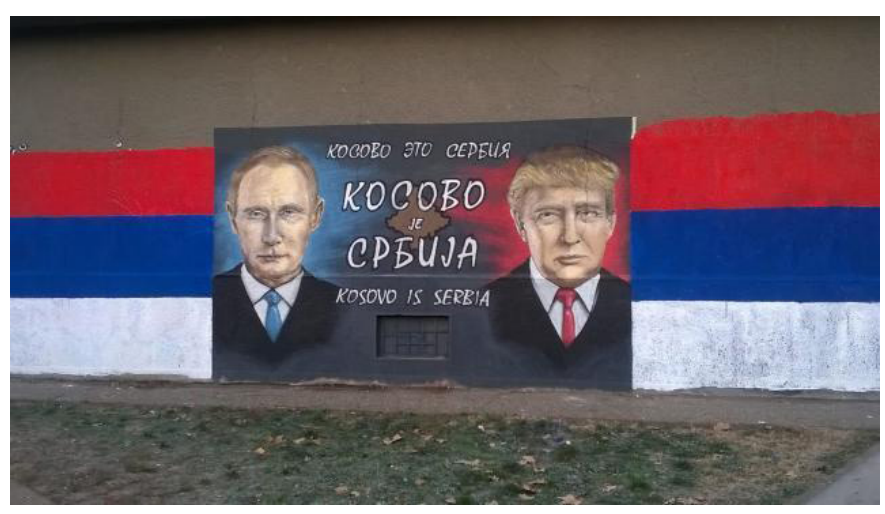

Source: https://thesrpskatimes.com/mural-shows-putin-trump-andmessage-kosovo-is-serbial. Retrieved February 26, 2021. 
The second mural is capturing the narration of the Serbian past and presence in relation to the Kosovo thread and is located in Kosovo in the northern part of Mitrovica.

\section{Photo IV}

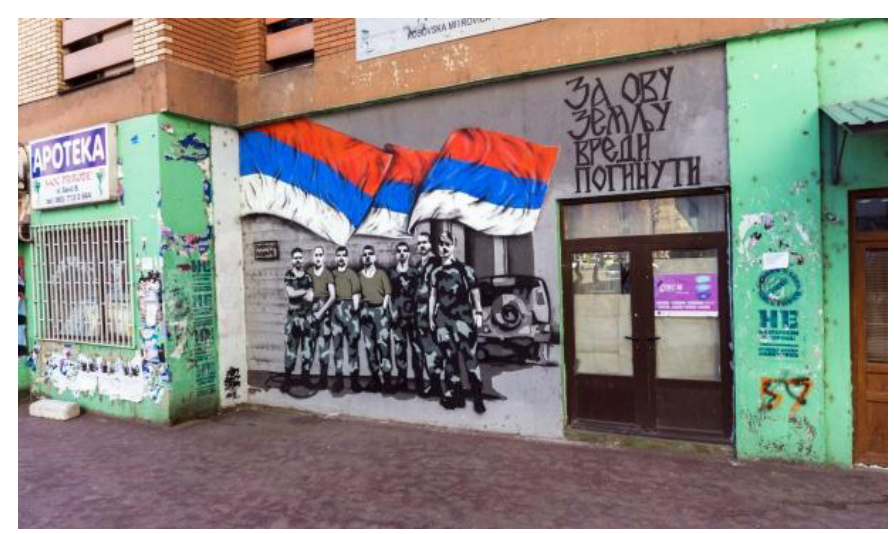

Source: https://balkaninsight.com/2019/01/16/bombs-and-bullets-fearand-loathing-in-north-kosovo-01-14-20191/. Photo: Stefan Milivojevic. Retrieved May 13, 2020.

The mural glorifies Serbian soldiers who fought under the colors of the Yugoslav flag during the conflict in Kosovo in 1999. The Cyrillic text next to the soldiers says: "It is worth dying for this country." This inscription, therefore, has a double meaning since it refers, on the one hand, to the Serbian struggle for Kosovo soil and, according to the rhetoric of Serbian messianism, to the renewed sacrifice made by the Serbs in the fight for Kosovo. On the other hand, it sees Kosovo as an integral part of Serbia. The term "country" refers here to Serbia together with Kosovo. Serbia, which was then part of the Federal Republic of Yugoslavia, did not accept the independence of the Kosovo province. This mural is thus also part of the rhetoric of victimization that was and still is present in Serbia. At this point, a short excerpt from a statement made by one of the interlocutors, Mirjana, a historian and essayist, can be brought up. When referring to the narrative on the Serbian past contained in historical and political narratives, she says that:

Victimization is the most constitutive feature of Serbian identity. This means that we have been victims of actions by our neighbors, great Western forces, traitors of our identity. Serbs have always been fighting. And talking about the fact that we are victims or that we are heroes is very much present in Serbia. And being a victim and a hero at the same time is rather controversial, but this is the specificity of the Serbs that they must also feel heroic. Our whole story is written in such a way that even if we were victims, we were still heroes and winners. So, all the victories of the Serbs are huge in the books. Victories aren't explained, but lost fights usually have an explanation on several pages.

This kind of simultaneous mix of heroism and victimization, presented as well on the mural shown above, is also an integral part of the Serbian narrative about Kosovo.

When talking about the contemporary perspective of the Kosovo issue present in Serbian discourse of politics, we can say that the strategies of Serbian politicians towards Kosovo continue to be strongly involved in the discussion about Kosovo's historically rooted belonging to Serbia. Unfortunately, things are no better on the Albanian side, which has been trying new ways to limit any role for Serbia (mostly in terms of the Serbian government) in the new state since independence. In Kosovo, tensions continue to be felt between the Serbian community (which is a minority) and the Albanian community (which is the majority of the country's population). 
The problem of the Kosovo Serbs is their political position suspended in the disputes between Belgrade and Pristina, but also economic issues (unemployment, illegal seizures of their land), as well as the deepening division and resentment over the years provoking ethnic incidents (between the Serbian and Albanian communities). ${ }^{29}$ Organized crime is also a big problem in the country. ${ }^{30}$ On the territory of Kosovo, two visions of its statehood, which are separate and mutually exclusive, also collide-the perspective of the Kosovo Serbs, related to the authority of bodies and institutions subordinate to the authorities in Belgrade, and the perspective of the Kosovo authorities. In this optics, the issue of autonomy for "Serbian" northern Kosovo is problematic in the context of the territorial integrality of the whole country (Pawłowski 2019). In 2018, the Serbian-Albanian conflict was significantly piled up due to the doubling of customs duties on Serbian goods by Kosovo. In this situation, in December 2018, the Serbian government even considered military intervention. In May 2019, after the action of Kosovo

\footnotetext{
${ }^{29}$ On the Serbian minority in Kosovo and the policy of the Republic of Serbia towards Serbs in Kosovo, see, for example, Korzeniewska-Wiszniewska (2017). The mentioned text is a multithreaded and comprehensive case study of Serbs as a minority in the post-Yugoslavian states. The researcher explains her decision to include in her analysis also the thread of the Kosovo Serbs due to "the actual state of Kosovo's functioning" between the states that do not recognize its independence (Serbia, Russia, China) and the international cooperation developed, however, within the state. Additionally, as the author points out: "The position of Serbs in the Kosovo area is the most difficult and complex of all analyzed cases due to the instability of the Kosovo state and the long-standing social boycott of Kosovo authorities by Serbs, which de facto prevents Serbian existence in that area" (Korzeniewska-Wiszniewska 2017:17 [trans. JW]).

${ }^{30}$ In the Western media, Kosovo was (and sometimes still is) described as a "gangster's paradise," as an area where organized crime, mainly drug trafficking, thrives. In this rhetoric, the Kosovo mafia clans are closely linked to criminal organizations from other European countries, especially Turkey, Albania, and Bulgaria. About Northern Kosovo analysis in terms of case study on the impact of organized crime, see, for example, Kemp, Shaw, and Boutellis (2013).
}

organized police in the north of Kosovo to break up criminal groups and smuggling gangs, Serbian President Aleksandar Vučić warned that he would react by force if the Serbs living there were attacked. There are many such flashpoints between the two countries in the calendar of recent history.

Today, the dialogue between Kosovo and Serbia is an important issue in the field of international politics. The negotiations are taking place under the auspices of the EU and the US, whose positions are also sometimes polarized. The EU and the US are pressuring Belgrade and Pristina to reach an agreement. Serbian and Kosovo elites are, to some extent, following this path. Therefore, the authorities of both countries are interested in stalling and prolonging the talks. This is done by periodically escalating tensions and presenting solutions that are unacceptable to the other side or the international community. An example of such actions were the border adjustment proposals presented in July 2018 by the Presidents of Serbia Aleksandar Vučić and Kosovo-Hashim Thaçi, ${ }^{31}$ which caused numerous controversies in local and international debates. Lately, on September 04, 2020, in Washington, Serbian President Aleksandar Vučić and Kosovo Prime Minister-Avdullah Hoti signed separate declarations with (former) US President Donald Trump on the normalization of mutual economic relations. The parties pledged to implement agreements reached earlier on the implementation of infrastructure and economic projects linking the two countries. ${ }^{32}$ The agreement states

\footnotetext{
${ }^{31}$ On November 05, 2020, Kosovo President Hashim Thaçi announced that he was stepping down due to the confirmation of an indictment for crimes against humanity and war crimes. On the same day, Thaçi traveled to The Hague to participate as a defendant in court proceedings before the Kosovo Specialist Chambers. Thus, he was the President of Kosovo from April 07, 2016 till November 05, 2020.

${ }^{32}$ In addition, the agreement means-the opening of a joint border post at Merdare, the joining of Kosovo to the Balkan so-
} 
also that Serbia is to suspend efforts to withdraw recognition of Kosovo's independence for a year, and Pristina will not seek membership in international organizations during that time. Because my research investigation is immersed in both the perspective of 2012 and the social and political threads that have shaped Serbian history and Serbian identity over the past few years, the briefly approximated theme of Kosovo was a very important issue tying together my research conclusions. Concerning the historical and social context of today's Serbia and the question of the formation of Serbian national identity, it is extremely important to return to the place where it all began for the Serbs-Kosovo-and to read its symbolism even today. This is what the interviewees did as well.

In the summary of this part of deliberations on Serbian narrative on present and the future, it should be added that the study that I conducted analyzing the interviews with Serbian elites representatives has established here several simultaneously functioning discourses that have an impact on the construction of Serbian national identity. These include: (1) pro-European discourse; (2) anti-European discourse; (3) Balkanism (in the sense of Serbian resentment based on a narrative about the domination of Europe and the discredit of the Balkan nations); (4) discourse about the Serbian identity entangled in the symbolism of Kosovo; (5) discourse of Serbian religion and tradition as the crucial domains of constructing Serbian national identity.

When talking about the latter, it should be emphasized that the relationship between the Serbian tra-

called mini-Schengen, mutual recognition of university diplomas, intensification of the search for persons missing during the 1998-1999 conflict, and respect for religious freedom were declared. dition and the formation of Serbian national identity, and the vision of Serbia represented by the Serbian Orthodox Church, is a significant aspect in creating the image of the Serbian state also in the present day. Encyclopedia of the Serbian People (Enciklopedija srpskog naroda [Ljušić 2008]) states that, in Serbia, apart from the state tradition (related to the historical awareness of the Serbian state, its forms, and political conditions) and the "mythical-epic tradition shaped within the framework of oral tradition," two other traditions considered to be fundamental can also be distinguished: the svetosavlje Orthodox and the folk tradition (Gil 2016:176 as cited in Ljušić 2008:1139-1140 [trans. JW]). As Dorota Gil (2016:176 [trans. JW]) notes, “The term svetosavlje is sometimes used as a synonym for Serbian Orthodoxy in the shape given to it by Saint Sava, ${ }^{33}$ but more often it defines ideologized Orthodoxy as an ethnic rather than religious category and is treated as a Serbian national idea." Moreover, in the process of redefining and reinterpreting Serbian cultural tradition since the 1990s, the return to medieval state-forming and spiritual traditions, which determine the elements of Serbian identity, plays a major role. ${ }^{34}$

As for the ways of interpreting Serbian national identity that I reconstructed in the statements of the interlocutors, due to the limitations of the text, I will only briefly mention them. Based on my analysis, I distinguished Serbian ethnic identity, Serbian linguistic identity, Serbian religious national identity, Serbian national identity understood as "ongoing

\footnotetext{
${ }^{33}$ Saint Sava (born 1175 or 1176, died 1235) is the first Archbishop of Serbia. He was counted among the most important saints of the Serbian Orthodox Church. He served in the Orthodox Church from 1219 to 1233 and was in favor of uniting the Orthodox Church with the state.

${ }^{34}$ To read more about Serbian Orthodox Church and Serbian spiritual tradition, see, for example, Gil (2005); Vukomanović (2008; 2011); Radić and Vukomanović (2014).
} 
identity" or "unfinished identity," and Yugoslavian identity. In addition, I also reconstructed two types of identity narratives that play a role in the construction of Serbian national identity-the narrative of the fusion of Serbian national identity with Kosovo and the narrative of anti-nationalism.

\section{Part III. Constructs of the "Other" and the} "Alien" in the Discourse on Serbian National Identity

The reconstruction of the images of "otherness" and "strangeness" present in the discourse on Serbian national identity has been underpinned by the theoretical context of "self-stranger" and the phenomenon of the "Other" in the understanding of Bernhard Waldenfels (2011). According to the author, the "Other" remains meaningfully different, while the "Alien" - threatening what is "own"-appears as hostile. In the studied discourse on Serbian national identity, I recognized a differentiation between the two rhetorical figures of the "Other" and the "Alien." Their coexistence is the result of the historical past of the Serbian nation and the very discursive process of constructing Serbian national identity. Thus, I agree with Waldenfels that the "Alien" is not simply something else. The encounter with what the "Alien" is involves the negation of belonging to what the "Alien" contains within itself and the need to protect its individuality. In this part of the article, I will not quote the interviews' fragments, but attempt to present the comprehensive collection of voices of the interlocutors, pointing out the main themes and conclusions of the analysis.

In my case study of Serbian national identity, I found that it is Europe (in the sense of Western Europe) and Albanians (as a nation living in Kosovo) that are two main rhetorical figures in the discourse about the "Alien" in relation to Serbian national identity. According to Waldenfels' concept, the "Alien" is associated here as hostile. However, in the case of the vision of Europe, the situation is more complex because two discourses on Europe as the "Other" and about Europe as the "Alien" are overlapping here. In a contemporary perspective marked by Serbia's claim to be a member of the EU, the opponents of accession reach for both discursive constructs, but the one about Europe as the "Other" is present much more often. And, the pro-European positions are looking for positive aspects of Serbia's accession to the European Community, seeing the membership as an opportunity for further democratization of the country and deepening of the international dialogue between Serbia and other European countries.

I also agree with Ana Russell-Omaljev (2016:116) that the Serbs, as part of the discourse of politics divided between the "First" and the "Other" Serbia, seek "others" among "their own," and that the categories of heroes and traitors celebrated or condemned for their national deeds are inextricably linked to the specificity of both political formations. The ideology that most inclines the discourse of politics in Serbia to recognize the "good" and the "bad" is nationalism, which, associated with the break-up of Yugoslavia (in the sense of the Socialist Federal Republic of Yugoslavia) and the Milošević regime, is supposed to illustrate the path to which Serbia should not return. The conducted study also reassured me that the post-Yugoslavian Serbian national identity cannot be analyzed in isolation from the discourse of Serbian nationalism of the 1990s. Today, many years after the fall of Milošević's rule, the legacy he has built up is still strongly present in the discourses of the "First" and the "Other" Serbia political narratives. The "Other Serbia" discourse 
focuses on blaming the Serbs as collectively responsible for Milošević's policies. The discourse of "First Serbia" continues to feel the nationalistic rush and justifies the Serbs as victims of the process of the break-up of Yugoslavia. There is also a recurrence of a certain hostility towards the neighboring republics, which usually resounds in themes related to the crimes of World War II, the Balkan armed conflicts of the 1990s, and the discussion about the status of Kosovo.

In the discourse of the "First Serbia," the still "living" nationalism was not so negatively connoted as that of the 1990s. Rather, the distinction between "good" in the patriotic sense of nationalism and its "bad" radical version was taken up here. Liberal and moderate nationalists, therefore, appeared in the political environment of the "First Serbia." The divisions on the political scene were also manifested by the two optics of the historical legacy of the last more than twenty years. Some politicians have persistently proclaimed a radical break with the ideological burden of Miloševićs time in the discourse on national history. The second group of political actors, like Boris Tadić, sought a policy of working together to rework the difficult past and prepare Serbia for international dialogue.

On the subject of perceiving Europe, it can be added that, in the discourse of the "Other Serbia," there is a belief that Europe is not an idea external to Serbia (Russell-Omaljev 2016:174). In this perspective, the perception of Europe as the "Other" is also transformed into an understanding of Europe as an element or part of the Serbianness. However, it is difficult to characterize in Serbian discourse of politics the mechanism behind the transformation of the perception of Europe as the "Alien" into a conscious pro-European political identity. Thus, considering the topics used since the 1990s, to define the framework of the official Serbian narrative on the past, present, and future nationalism, war crimes, and auto-chauvinism (Russell-Omaljev 2016:206) should be mentioned. Based on the analyzed statements of the representatives of symbolic elites, I was able to verify that the redefinition of the notions such as Serbian nationalism (in terms of its version from the late 80s and 90s of the XX century), Serbian war crimes (in the optics of the armed conflicts in the 90s), and Serbian messianism (in terms of Serbian discourse of politics rooted in national myths which are being transformed into the political ones and Serbian spiritual tradition, both entangled in dormant resentments of the suffering nation) are necessary to define in the official discussion of Serbia's historical past the community of past experiences instead of following divided readings of the recent history.

When talking about "Others" and "Aliens" in the discourse on Serbian national identity, the interlocutors are focused on the already mentioned pro- and anti-European discourses. It is important to point out that the latter is constructed most often in relation to the Serbian political past. The first, pro-European one, uses discursive constructive strategies and operates with the topos of being part of Europe and the topos of the periphery of Europe, constructs a desire for collective pro-European identification. In the anti-European discourse, on the other hand, in the statements of the interlocutors, it is the sense of "not being part of Europe" that is most resounding in the reconstruction of the anti-European approach. This discourse is strongly influenced by the already mentioned Balkanism. However, much more important seems the anti-European discourse created in the discourse of Serbian national identity concerning recent history. Public discourse in Ser- 
bia-as the interlocutors mentioned-refers here to the marginalization or worse treatment of their nation by Europe in comparison with other former $\mathrm{Yu}-$ goslavian republics. There is also the "disappointment" in Europe's stance, first of all, on the question of its unwillingness to take responsibility for the conflicts in the Balkans that took place in the 1990s, and then-Europe's role in the process of granting independence to Kosovo, and the omission of Serbia's views on this matter. The latter issue was particularly important for a return in the discourse on Serbian national identity to seeing Europe as a hostile "Alien." The anti-European discourse present in Serbia may thus seek, through discursive deconstructive strategies, to destroy the manifestations of European identity in situations where Serbian society is seeking it and tries to reconstruct it within its national identity.

Based on the research conclusions, it should be noted that, in the linguistic construction of the "Other" and the "Alien," the tensions in the discourse on Serbian national identity are marked by the conflicts between what is "Serbian" and what is "non-Serbian," inscribed in the dichotomous "self-other" relation. The images of "Aliens" in the period of the 1980s and the first half of the 1990s reconstructed in my study include (a) anti-European discourse; (b) anti-Western discourse (West understood here as the US); (c) anti-Croatian discourse; (d) anti-Albanian discourse; (e) anti-Bosnian discourse.

Since 1999, after the NATO bombings in the Federal Republic of Yugoslavia, in Serbian public discourse, the discourse of politics and symbolic elites, the anti-Western narrative is appearing. Since 2000, after the collapse of Milošević's regime, the anti-European discourse was still present, but throughout the next few years it focused more on a vision of Europe as the "Other" rather than the "Alien." In 2008, the intensification of the anti-European discourse after the declaration of Kosovo's independence brought again to the public and political discourses in Serbia the perception of Europe as the "Alien." Then, in 2012, in Serbian public discourse and on the Serbian political scene occurred an intensification of the anti-Croatian and anti-European discourse after the Hague Tribunal released the Croatian generals (Ante Gotovina and Mladen Markač) who participated in the armed conflicts in the Balkans in the 1990s. Thus, in recent years, in the discourse of politics in Serbia, what is visible is the separation between the intensification of the anti-European discourse, resulting, among other things, from the growing conflict over the functioning of an independent Kosovo, and the still strong pro-European attitude. The discourse on Serbian national identity is also still entangled in the visions on Serbianness produced by the "First Serbia" and the "Other Serbia." In this way, a discourse of the identity based on tradition, conservative, nurturing national symbols meets the pro-European discourse-liberal and critical towards nationalism.

In addition, a still difficult and polarizing discourse of the politics and related social perceptions in Serbia of the issue is the topic of the NATO bombing in 1999. An example of the topicality of this subject can be seen in the situation when, during the celebration of the $20^{\text {th }}$ anniversary of the commemoration of these events (on March 24, 2019) in the atmosphere of Serbia turning towards the future and moving away from attitudes hostile to the West, the leader of the Serbian Radical Party, Vojislav Šešelj, and his supporters set the EU and NATO flags on fire. Since 1999, in the discourse on post-Yugoslavian Serbian national identity, the NATO forces, in which the Americans played a major role, have been 
seen as the enemy of the Serbian nation. Also, in his statements and interviews, Aleksandar Vučić, the President of Serbia, stressed that Serbia will not join NATO or any other military structure in the near future. In Belgrade (to this day), the words Neću NATO (I don't want NATO), which carries another Serbian resentment, can be found on the buildings.

\section{Photo V}

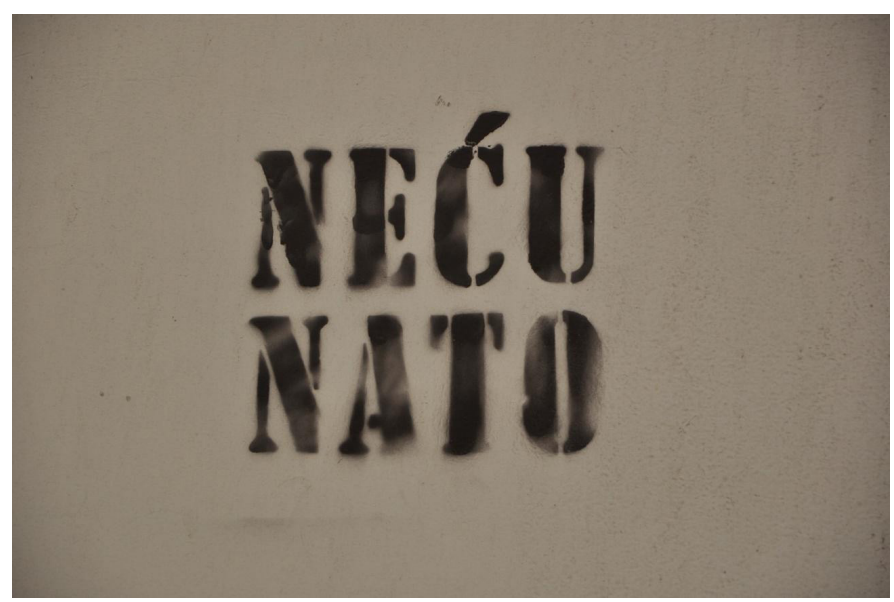

Source: Self-elaboration.

\section{Closing Remarks}

The study of the discourse on Serbian national identity enabled us to discuss its specificity within the framework of the three main analytical themes listed in this article. In the reconstruction of the Serbian political past, the most noteworthy is the narrative on Yugoslavian identity. As I verified in my research, the Yugoslavian identity as a phenomenon escapes the discursive order of inference and historical frames of analysis. Thus, I embrace the Yugoslavian identity as part of the discourse on Serbian national identity and as the dimension of the sense of identity. According to the interlocutors, the Yugoslavian identity, apart from its political understand- ing as to the national identity of the inhabitants of Yugoslavia, inscribed in the idea of Titoism, is the identity with which many Serbs identified, and still identify. The memory of Yugoslavia, recognized also as a part of the Serbian collective memory, should also be understood in terms of the communicative memory (Assmann 2008; Assmann 2013; Kaźmierska 2012). The generation of "carriers" of this memory is, therefore, the main condition for its existence. As I indicated in the article, my research allowed me to conclude that the phenomenon of the Yugoslavian identity also eludes the classical accounts of nostalgia for past realities. It is attributed, among other things, to nostalgia for the communist reality in post-socialist countries. Yugonostalgia can wrongly deprive the Yugoslavian identity of its meaning, inscribed in the perspective of individual identifications. It is only a certain part of the experiences that the Yugoslavian reality has rooted in the biographical memory of the individuals who still identify themselves as Yugoslavs.

Thus, the sociological view of Yugoslavian identity can fit into two ways of interpreting this phenomenon. The first is related to the perception of this identity as an element of political illusion and social creation. Its development would involve the reconstruction of the mechanisms of control and power in the discourse about the community of Yugoslav states both within and outside the discourse. In this perspective, the notion of yugonostalgia would also need to be analyzed more broadly to see to what extent it is part of contemporary mechanisms that sustain the functioning of the phenomenon of nostalgia among post-socialist countries in Europe. And to what extent is this a creation of a discourse of power in the post-Yugoslav republics produced to obscure other important themes related to the Yugoslav past. The second way of interpreting the phenomenon of 
Yugoslavian identity is related to the optics presented in this text. The Yugoslavian identity appears here as part of the intersubjective cultural reality. As a community of identifying meanings. Thus, an important research question arises here about the mechanisms of sustaining and destroying this still existing identity, which, despite the collapse of Yugoslavia, has survived on the level of individual and collective identification. The answer to this question would require studying the phenomenon of Yugoslavian identity much more broadly than the perspective I focused on in my research. It would be valuable to reach out to interlocutors from other post-Yugoslav republics and compare their ways of talking about Yugoslavian identity with the presented Serbian context. ${ }^{35}$

On the other hand, the discourse on the Socialist Federal Republic of Yugoslavia at the historical and social level is associated with the memory of Titoism, communism, civil religion, and nationalism awakened in the 1980s. It is also a time of suppressing the memory of World War II, and thus separating this area of official memory (in Serbia and other Yugoslav republics) through the emergence of the silent SEP36 (Czyżewski, Dunin, and Piotrowski 1991). This is about "blurring" in memory. A kind of experience in which the memory is obliterated, pushed into the background, and the resources of categorization are obscured. Thus, both in Serbia and in other post-Yugoslav republics, not only the memory of World War II, but also the memory of the Federation of the Yugoslav states and its disintegration, associated with the time of difficult experiences of

${ }^{35}$ In the context of the duration of this identity, the use of the biographical research method is also worth considering.

${ }^{36}$ The term "SEP" means somebody's else problem, in other words, it means a silenced matter, considered to be someone else's issue. war, conflict, and crisis, is subject to the processes of separation. Referring to the assumption that, in a CDA, it is important not only to expose the hidden procedures and discursive strategies used to reproduce a legitimate image of the reality, but also to identify those threads that have been excluded from the analyzed discourse-such threads include in the discourse on Serbian collective memory the listed moments of memory about post-war Yugoslavia and the period of the 1990s.

As I mentioned in the text, many of the statements contained references to the biographical experiences of the representatives of the symbolic elites, as a result of their direct involvement in the operation of the process I was analyzing. What was interesting to me, although I expected that the interviews might be dominated by the discourse on the armed conflicts of the 1990s, ${ }^{37}$ the interviewees, except for a few brief mentions, did not turn to the war story. This may have been due to the time lapse between the end of the war in Bosnia and Herzegovina, the Serbo-Croat conflict, and the fighting over Kosovo until the time of my research. I assume that Serbia was not a country where the specter of war was felt deeply. Certainly, in the early 1990s, the country was in an economic crisis, and hyperinflation was also coming to a head as a result of sanctions introduced by the international community, which made the population feel the deteriorating living conditions very strongly. In addition, Slobodan Milošević was consolidating his rule on the political scene. However, it was not in Serbia that mass atrocities occurred. For many years, the story of war, through the manipulative actions of the me-

\footnotetext{
${ }^{37}$ It is important to note in the concluding section that warfare in the 1990s in the Balkans took place in 1991 in Slovenia, 19911995 in Croatia, 1992-1995 in Bosnia, and 1998-1999 in Kosovo and Serbia (the 1999 NATO bombing).
} 
dia and the ruling elites in Serbia, was removed from the list of topics worth talking about. In such a created reality, one could even believe the narrative that there was no war at all.

In conclusion, it can be added as well that the internal conflicts between the "First Serbia" and the "Other Serbia" also play an important role in the construction of the discourse on Serbian national identity. The two discursive formations not only differ from each other in terms of identity, but they also present different visions of Serbianness. In the case of the "First Serbia," the discourse on Serbian national identity is still strongly linked to the symbolic dimension of Kosovo and national tradition. In the case of the "Other Serbia," this discourse is pro-European, anti-nationalist, democratic. In such an approach, the two Serbia's identities do not find common solutions, but rather strive for a constant differentiation. It is also difficult to say whether the "Third Serbia" emerging in the public discourse, which is a structure that has not yet been described more precisely, will have a chance to reconstruct or break down the ongoing division in the near future.

In closing the discussion, I would like to address as well the phenomenon of Serbian nationalism in its contemporary dimension and its understanding in Michael Billig's (2008) concept of banal nationalism. Based on the socio-historical context of the formation of Serbian nationalism, and referring to its contemporary optics, I conclude that the statement about the existence of everyday, banal nationalism in Serbia, which might seem an obvious conclusion in relation to this concept, still requires a comment based on the conclusions of my research. Like Ivana Spasić (2017), I think that Serbian banal nationalism is a little bit out of line with Billig's approach.
This means that although it can undoubtedly be considered that the social practices proper to banal nationalism, in which it is reproduced in the form of national semantics and rhetoric, are also an integral part of the Serbian context. It is, however, in the case of Serbia, that banal nationalism is seldom cold and unconscious. Spasić emphasizes that there are many "positive," "non-developing" forms of Serbian manifestations, but "underneath the thin crust of banality there usually lurks a kind of nationalism which, if it not outright hot, at any rate, is impassioned, resentful or oversensitive" (Spasić 2017:41). The justification for such an understanding of Serbian banal nationalism can be found in the functioning of Serbian national rhetoric. Within its framework, questions about the Serbian nation, the Serbian identity are still too strongly marked by the need to value the difference between "us" and "them." In addition, in the case of Serbia, in national rhetoric so entangled in national myths, the boundary between the undervalued evocation of stories about the Serbian nation or its symbolism and conscious and manipulated use is still very thin.

Statements gathered from the representatives of Serbian elites and constant conversations with some of the interlocutors when I was back in Poland, analyzed political statements, and long-term study of the discourse on Serbian national identity made me familiar with the enormity of the "bad" memory that this discourse has to face to release itself from Balkan demons of the past and dormant resentments. The issues I examined, however, related to the "resentment" of Serbian nationalism are not just a particular feature of this case. The contemporary political and social transformations taking place in Europe show that the rise of extreme national visions is a sign of the times, an image of the universalization of the processes that have so far been considered in rather 
particularistic categories. The following words seem to be the proper metaphor for understanding the Serbian case: "The repressed has returned, and its name is nationalism" (Ignatieff 1993:11). Thus, to try to understand and reconstruct the Serbian past and

\section{References}

Assmann, Aleida. 2013. Między historia a pamięcia. Antologia [Between History and Memory. Anthology]. Warsaw: Wydawnictwo Uniwersytetu Warszawskiego.

Assmann, Jan. 2008. Pamięć kulturowa. Pismo, zapamiętywanie i polityczna tożsamość w cywilizacjach starożytnych [Cultural Memory and Early Civilization: Writing, Remembrance, and Political Imagination]. Warsaw: Wydawnictwo Uniwersytetu Warszawskiego.

Babić, Marko. 2012. “Aporie tożsamości. Serbowie, Chorwaci i Unia Europejska [Identity Aporias. Serbs, Croats, and the European Union]." Pp. 101-129 in Problemy aksjologiczne w relacjach Unii Europejskiej z Bałkanami [Axiological Problems in Relations between the European Union and the Balkans], edited by M. Babić and F. Gołembski. Warsaw: Oficyna Wydawnicza Aspra.

Berger, Peter and Thomas Luckmann. 1966. The Social Construction of Reality: A Treatise in the Sociology of Knowledge. New York: Doubleday \& Company.

Bieber, Florian. 2002. "Nationalist Mobilization and Stories of Serb Suffering. The Kosovo Myth from $600^{\text {th }}$ Anniversary to the Present." Rethinking History 6(1):95-110.

Billig, Michael. 2008. Banalny nacjonalizm [Banal Nationalism]. Cracow: Wydawnictwo Znak.

Blagojević, Marina. 2003. "War on Kosovo: A Victory for Media." Pp. 166-182 in Understanding the War in Kosovo, edited by F. Bieber and Ž. Daskalovski. London: Frank Class Publishers.

Čolović, Ivan. 2001. Polityka symboli. Eseje o antropologii politycznej [The Politics of Symbols in Serbia. Essays in Political Anthropology]. Cracow: Wydawnictwo Universitas.

Czyżewski, Marek, Kinga Dunin, and Andrzej Piotrowski, eds. 1991. Cudze problemy. O ważności tego, co nieważne. Analiza dyskursu publicznego w Polsce [Others' Problems. On the Importance present, it is necessary to remember that in this social and political reality it is not only important how "the past influences the present," but also "how the present manipulates the past, which is decisive in the Balkans" (Ignatieff 1993:29).

of What Is Unimportant. Analysis of Public Discourse in Poland]. Warsaw: Wydawnictwa Akademickie i Profesjonalne Spółka.

Czyżewski, Marek, Sergiusz Kowalski, and Andrzej Piotrowski, eds. 1997. Rytualny chaos. Studium dyskursu publicznego [Ritual Chaos. A Study of Public Discourse]. Cracow: Wydawnictwo Aureus.

Dimitrijević, Nenad. 1999. "Words and Death: Serbian Nationalist Intellectuals." Pp. 119-148 in Intellectuals and Politics in Central Europe, edited by A. Bozóki. Budapest: Central European University Press.

Foucault, Michel. 1977. Archeologia wiedzy [The Archeology of Knowledge]. Warsaw: PWN.

Gil, Dorota. 2005. Prawostawie, historia, naród. Miejsce kultury duchowej w serbskiej tradycji [Orthodoxy, History, Nation. The Place of Spiritual Culture in the Serbian Tradition]. Cracow: Wydawnictwo Uniwersytetu Jagiellońskiego.

Gil, Dorota. 2016. “Tradycje serbskiej kultury - modele skodyfikowane i wykreowane [Traditions of Serbian Culture-Codified and Created Models]." Studia Litteraria Universitatis Iagellonicae 11(4):175-186.

Gordy, Eric D. 1999. The Culture of Power in Serbia. Nationalism and the Destruction of Alternatives. Pennsylvania: The Pennsylvania State University Press.

Gordy, Eric D. 2005. "Postwar Guilt and Responsibility in Serbia: The Effort to Confront It and Effort to Avoid It." Pp. 166-191 in Serbia Since 1989: Politics and Society under the Milošević and After, edited by S. P. Ramet and V. Pavlaković. Seattle, WA: University of Washington Press.

Hymes, Dell Hathaway. 1978. “What Is Ethnography?" Working Papers in Sociolinguistics (45):45-71. 
Ignatieff, Michael. 1993. Blood and Belonging: Journeys into the New Nationalism. London: Chatto \& Windus.

Jagiełło-Szostak, Anna. 2012. “Jugonostalgia - pozostałość po wieloetnicznej Jugosławii [Jugonostalgia-A Remnant of Multi-Ethnic Yugoslavia]." Wschodnioznawstwo 6:239-256.

Judah, Tim. 2000. Kosovo. War and Revenge. London: Yale University Press.

Judah, Tim. 2002. “Milošević on Trial.” Survival. Global Politics and Strategy 44(2):157-167.

Jusić, Tarik. 2009. "Media Discourse and the Politics of Ethnic Conflict: The Case of Yugoslavia." Pp. 21-38 in Media Discourse and the Yugoslav Conflicts. Representations of Self and Other, edited by P. Kolstø. Farnham, Burlington: Ashgate Publishing Company.

Kaźmierska, Kaja. 2012. “Współczesna pamięć komunikacyjna i kulturowa. Refleksja inspirowana koncepcją Jana Assmanna [Contemporary Communicative and Cultural Memory. A Reflection Inspired by Jan Assmann's Concept]." Pp. 43-62 in Kultura jako pamiecć. Posttradycjonalne znaczenie przeszłości [Culture as Memory. The Post-Traditional Meaning of the Past], edited by E. Hałas. Cracow: Zakład Wydawniczy Nomos.

Kemp, Walter, Mark Shaw, and Arthur Boutellis. 2013. The Elephant in the Room: How Can Peace Operations Deal with Organized Crime. New York: International Peace Institute.

Korzeniewska-Wiszniewska, Mirella. 2017. Serbowie jako mniejszość w warunkach transformacji politycznej w państwach byłej Jugosławii 1995-2016 [Serbs as a Minority under Conditions of Political Transformation in the States of Former Yugoslavia 1995-2016]. Cracow: Księgarnia Akademicka.

Kovačević, Dušan. 2008. Dvadeset srpskih podela (Srba na Srbe) [20 Serbian Divisions (Serbs to Serbs)]. Belgrade: Laguna Knjižare.

Krzyżanowski, Michał. 2008. “Konstrukcja tożsamości narodowych i europejskich w polskim dyskursie politycznym po roku 1989: analiza dyskursywno-historyczna [The Construction of National and European Identities in Polish Political Discourse after 1989: A Discursive-Historical Analysis]." Pp. 267304 in Krytyczna analiza dyskursu. Interdyscyplinarne podejście do komunikacji społecznej [Critical Discourse Analysis. An Interdisciplinary Approach to Social Communication], edited by A. Duszak and N. Fairclough. Cracow: Wydawnictwo Universitas.

Lessl, Thomas. 1989. “The Priestly Voice.” Quarterly Journal of Speech 75(2):183-197.
Lewandowski, Piotr. 2015. Mit i czas polityczny [Myth and Political Time]. Będzin: Wydawnictwo Internetowe e-bookowo.

Ljušić, Radoš, ed. 2008. Enciklopedija srpskog naroda [Encyclopedia of the Serbian People]. Belgrade: Zavod za udžbenike.

Malešević, Siniša. 2002. Ideology, Legitimacy and the New State. Yugoslavia, Serbia and Croatia. London: Routledge Series: Nationalism and Ethnicity.

Nikolić, Lazar. 2003. "Ethnic Prejudices and Discrimination: The Case of Kosovo." Pp. 53-75 in Understanding the War in Kosovo, edited by F. Bieber and Ž. Daskalovski. London: Frank Class Publishers.

Patalakh, Artem. 2018. "Emotions and Identity as Foreign Policy Determinants: Serbian Approach to Relations with Russia." Chinese Political Science Review 3(4):495-528.

Pawłowski, Konrad. 2016. Konflikt serbsko-albański w Kosowie w latach 1999-2014. Charakterystyka, uwarunkowania i formy konfliktu społecznego [The Serb-Albanian Conflict in Kosovo 1999-2014. Characteristics, Determinants, and Forms of Social Conflict]. Lublin: Wydawnictwo Uniwersytetu Marii Skłodowskiej-Curie.

Pawłowski, Konrad. 2019. Państwowość Kosowa. Geneza, uwarunkowania, współczesność [Statehood of Kosovo. Genesis, Determinants, Contemporaneity]. Lublin: Wydawnictwo Uniwersytetu Marii Skłodowskiej-Curie.

Pešić, Vesna. 1995. “Nacionalni sukobi. Raspad Jugoslavije i rat za nacionalne drzave [National Conflicts. The Breakup of Yugoslavia and the War for Nation State]." Republika 7(129):I-XXVIII.

Pike, Kenneth Lee. 1967. Language in Relation to a Unified Theory of the Structures of Human Behavior. The Hague: Mouton.

Radić, Radmila and Milan Vukomanović. 2014. "Religion and Democracy in Serbia Since 1989: The Case of the Serbian Orthodox Church." Pp. 180-211 in Religion and Politics in Post-Socialist Central and Southeastern Europe: Challenges Since 1989, edited by S. P. Ramet. New York, London: Palgrave Macmillan.

Reljić, Dušan. 1988. Pisanje smrti: mediji u vremenima sukoba [Writing Death: Media in Times of Conflicts]. Belgrade: Radio B92.

Russell-Omaljev, Ana. 2016. Divided We Stand: Discourses on Identity in 'First' and 'Other' Serbia. Stuttgart: ibidem Press.

Schütz, Alfred. 2012. O wielości światów. Szkice z socjologii fenomenologicznej [About the Multitude of Worlds. Sketches in Phenomenological Sociology]. Cracow: Zakład Wydawniczy Nomos. 
Schütz, Alfred and Thomas Luckmann. 1973. The Structures of the Life-World. Evanston: Northwestern University Press.

Spasić, Ivana. 2017. “The Universality of Banal Nationalism, or Can the Flag Hang Unobtrusively outside a Serbian Post Office." Pp. 31-51 in Everyday Nationhood. Theorising Culture, Identity and Belonging after Banal Nationalism, edited by M. Skey and M. Antonsich. London: Palgrave Macmillan.

Spasić, Ivana and Tamara Pertrović. 2012. "Varieties of 'Third Serbia."' Pp. 219-244 in Us and Them: Symbolic Divisions in Western Balkans Societies, edited by P. Cveričanin and I. Spasić. Nis: Center for Empirical Cultural Studies of South-East Europe.

Subotić, Jelena. 2011. "Europe Is a State of Mind: Identity and Europeaization in the Balkans." International Studies Quarterly 55:309-330.

Tannock, Stuart. 1995. “Nostalgia Critique." Cultural Studies 9(3):453-464.

Thompson, Ewa. 2006. "Sarmatyzm i postkolonializm. O naturze polskich resentymentów [Sarmatism and Postcolonialism. On the Nature of Polish Resentments]." Europa, Tygodnik Idei 46:11-18.

Thompson, Mark. 1999. Forging War: The Media in Serbia. Croatia, Bosnia and Herzegovina. London: University of Luton Press.

Todorova, Maria. 2008. Bałkany wyobrażone [Imagining the Balkans]. Wolowiec: Wydawnictwo Czarne.

van Dijk, Teun A. 1993. Elite Discourse and Racism. Newbury Park: Sage.

Volčič, Zala. 2005. "The Notion of 'the West' in the Serbian National Identity." European Journal of Cultural Studies 8(2):155-175.

Vukomanović, Milan. 2008. "Serbian Orthodox Church as a Political Actor in the Aftermath of October 5, 2000." Politics and Religion 1(2):237-269.

Vukomanović, Milan. 2011. "The Serbian Orthodox Church: Between Traditionalism and Fundamentalism." Pp. 148-
170 in Fundamentalism in the Modern World (Vol. 1), edited by U. Mårtensson et al. London, New York: I. B. Tauris \& Co Ltd.

Waldenfels, Bernhard. 2011. Phenomenology of the Alien: Basic Concepts (Studies in Phenomenology and Existential Philosophy). Evanston: Northwestern University Press.

Wasilewski, Jacek. 2006. Retoryka dominacji [The Rhetoric of Domination]. Warsaw: Wydawnictwo Trio.

Williams, Raymond. 1973. The Country and the City. Oxford: Oxford University Press.

Wodak, Ruth. 2015. The Politics of Fear. What Right-Wing Populist Discourses Mean. London: Sage.

Wodak, Ruth and Gilbert Weiss. 2004. “Visions, Ideologies and Utopias in the Discursive Construction of European Identities: Organising, Representing and Legitimising Europe." Pp. 225252 in Communicating Ideologies: Language, Discourse and Social Practice, edited by M. Pütz, J. A. Neff-van Aertselaer, and T. A. van Dijk. Frankfurt: Peter Lang.

Wodak, Ruth et al. 2009. The Discursive Construction of National Identity. Edinburgh: Edinburgh University Press.

Wygnańska, Joanna. 2020. Oswajając bałkańskie demony. Rzecz o Serbii. Dyskursywne konstruowanie serbskiej tożsamości narodowej [Taming the Balkan Demons. The Thing about Serbia. Discursive Construction of Serbian National Identity]. Lodz: Wydawnictwo Uniwersytetu Łódzkiego.

Zdravković, Helena. 2006. "The Vernacular Discourses of Historical Victimage of Kosovo Serbs and Albanians." Balcanica XXXVI:83-112.

Zieliński, Bogusław. 2001. "Kosowo w serbskiej kulturze i tradycji [Kosovo in Serbian Culture and Tradition]." Pp. 15-48 in Jezzyk, literatura i kultura Stowian [Language, Literature, and Culture of the Slavs], edited by B. Zieliński. Poznan: Wydawnictwo Naukowe UAM.

Živković, Marko. 2011. Serbian Dreambook. National Imaginary in the Time of Milošević. Bloomington: Indiana University Press.

\section{Citation}

Wygnańska, Joanna. 2021. "Between Political Myths, Dormant Resentments, and Redefinition of the Recent History: A Case Study of Serbian National Identity." Qualitative Sociology Review 17(2):38-68. Retrieved Month, Year (http://www.qualitativesociologyreview.org/ENG/archive_eng.php). DOI: http://dx.doi.org/10.18778/1733-8077.17.2.03 